\title{
化学生態学的手法による湖沼生態系におけるラン藻が関与する諸現象の解明
}

\author{
原田健一
}

\section{Elucidation of Phenomena Involving Cyanobacteria in Freshwater Ecosystem by Chemically Ecological Approach}

\author{
Ken-ichi Harada \\ Faculty of Pharmacy, Meijo University; 150 Yagotoyama, Tempaku-ku, Nagoya 468-8503, Japan.
}

(Received June 28, 2021)

\begin{abstract}
Lakes Sagami and Tsukui are reservoirs constructed by connecting to the Sagami River. Because of eutrophication of the lakes, cyanobacteria have appeared every year. This review deals with phenomena related to occurrence of cyanobacteria that have been observed for 40 years since 1974 at the lakes. These 40 years of observations raised three interesting issues including the retention of cyanobacteria on their surfaces. These phenomena have been attributed to the usual factors, such as illuminance, nutrition and water temperature, but our research results suggested that they cannot be resolved without the introduction of another factor. We have attempted to elucidate various phenomena involving cyanobacteria in lake ecosystems by chemical ecological methods using volatile organic compounds (VOCs) produced by the cyanobacteria as indicators. One of the VOCs, $\beta$-cyclocitral, was significantly involved in the above phenomena, which was considered to be produced by the carotenoid cleavage dioxygenase (CCD) of the cyanobacteria. $\beta$-Cyclocitral was not produced in the two known CCDs, but two additional CCDs to Microcystis aeruginosa participated to produce the $\beta$-cyclocitral. These CCDs did not directly produce $\beta$-cyclocitral, but it was accumulated in cells as their precursors. The released $\beta$-cyclocitral underwent a Baeyer-Villiger-like oxidation. It was speculated that Microcystis activated the CCD genes through density stress and produced $\beta$-cyclocitral, which acted as an allelopathic substance. As a result, the number of cells of cyanobacteria decreased, and the resulting nitrogen and phosphorus were fed to the living cyanobacteria. It is postulated that this "quorum sensing" was functioning in the above-mentioned issues.
\end{abstract}

Key words_— chemical ecology; water bloom; $\beta$-cyclocitral; density stress; quorum sensing

\section{1.はじめに}

1-1. 背景水は地球環境において必要不可欠 な物質であり，物質や熱の循環を始めとして様々な 機能を有している。液状で保持された水は，良質な 溶媒で，生物体における最大の構成要素であり，生 命の発展においても非常に重要な因子であった。地 球は“水の惑星” とも称されるが，水は地表の 7 割 を覆っているものの, 地球全体に対する質量比は $0.05 \%$ と少ない。体積としては 14 億 $\mathrm{km}^{3}$ になる が，そのうち 96.5\%が海水であり，塩水地下水を 除くと淡水は $2.5 \%$ とる。 さらに，これらの大半 は水河など凝固した形で存在しており，地下水や河

名城大学薬学部（干468-8503 名古屋市天白区八事山 150 番地)

e-mail: kiharada@meijo-u.ac.jp

本総説は, 2020 年度退職にあたり在職中の業績を中心

に記述されたものである。
川，湖沼としての淡水はわずか $0.8 \%$ である，そし て，実際に利用し易い状態で存在している河川・湖 沼の淡水に限ると， $0.01 \%$ に過ぎない. 人類やほと んどの陸上生物は，わずか $0.01 \%$ の水を分け合っ て生きていることになる. 現在，これらの貴重な水 源は大量消費により発生した副産物や廃棄物により 污染され，河川や湖沼では富栄養化が進行してい る. 富栄養化は環境問題の 1 つであり, 生活排水や 工業廃水, 化学肥料や農薬の流入により栄養塩が過 剰となった状態である。富栄養化が進んだ閉鎖水域 では夏季になるとラン藻類が異常増殖し，水面が緑 色に覆われる水の華 (Water bloom), 通称アオコ という現象が生起する (Fig. 1). 1,2) この現象は悪 臭・毒の産生, 生態系の破壊や飲用水としての品質 低下など様々な問題を引き起こしている。 これまで にアオコの対策を目的として，ラン藻に関する研究 は昭和中期より盛んに進められてきた，生理学，生 


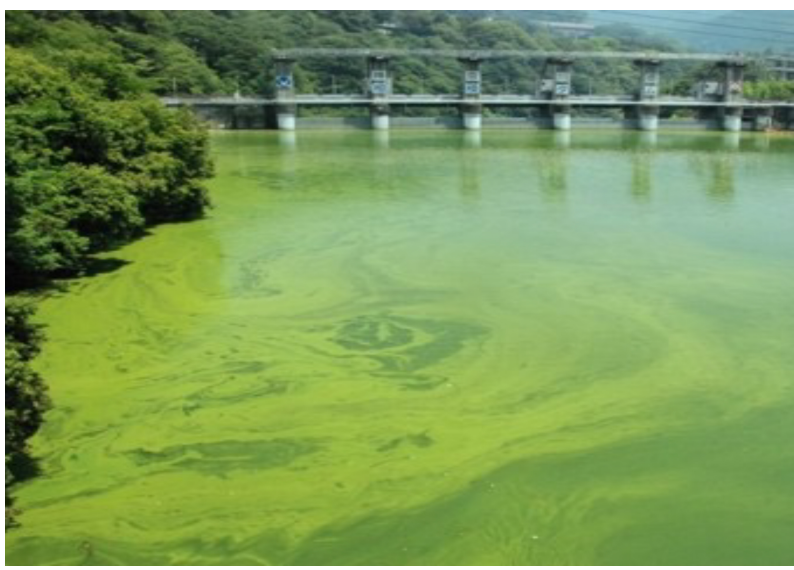

Fig. 1. Water Bloom of Cyanobacteria at Lake Sagami (Color figure can be accessed in the online version).

態学, 毒性学や処理方法の探索, 発生予測, 水処理 など様々なアプローチで研究が進められ多くの知見 が積み上がっているものの, 最終的な解決にはいま だ至っていないのが現況である。ラン藻はおよそ 35 億年前から生息したとされている原核細胞生物 であり，細菌類でありながら光合成を行うための葉 緑素を有している。地球上で初めて光合成を行った 生物でもあり，今日の酸素呼吸型の生物が生息でき る環境を作り上げた功労者でもある。また，分類学 においては植物，あるいは微生物としても扱われて きたが，現在は「cyanobacteria」として細菌に位 置付けられている. 1,2)

神奈川県北部にある相模湖・津久井湖では 1967 年以降毎年ラン藻が発生し，大きな問題となってい る. 1997 年，神奈川県企画部科学技術振興課（当 時）が科学技術庁の補助金を得て科学技術総合研究 委託費地域先導研究「相模湖・津久井湖の藻類によ る污濁機構解明とその浄化・資源化技術に関する研 究」をテーマに研究者を招集し, 平成 9-11 年度 (1997 年 4 月-2000 年 3 月) に神奈川県の研究機関, 大学, 国の研究機関等の研究者が 5 部門 14 テーマ について研究を行つた。 その中で, 神奈川県衛生研 究所は, 「藻類の産生するカビ臭と有毒化合物の制 御に関する研究」のなかの「生物学的手法によるか び臭等の分解に関する研究」のテーマの下，外部結 集研究者であった原田の協力で相模湖・津久井湖か ら溶藻性微生物及び microcystin 分解性微生物の探 索を行い，溶藻活性を持つ 11 株の放線菌と 8 株の 細菌, microcystin 分解性細菌 3 株を単離した。
1-2. 相模湖及び津久井湖における 40 年（19742013 年）間の観察＼cjkstart相模湖は，富士五湖の 1 つ である山中湖を水源とする全長 $113 \mathrm{~km} の$ 相模川 （山梨県下では桂川と呼ばれる）の河口から約 $50 \mathrm{~km}$ 上流に 1947 年に建造された相模ダムにより せき止められたダム湖である。一方，津久井湖は相 模湖の約 $10 \mathrm{~km}$ 下流に 1965 年に建造された城山夕゙ ムによりできた人工湖である（Fig. 2)，筆者の共 同研究者の一人である有井は，相模湖及び津久井湖 を 40 年間（1974-2013 年）にわたりラン藻に関す る種々の調査を行った. Figure 3 には相模湖及び津 久井湖に出現するラン藻類の顕微鏡写真を示す。発 生したラン藻の一部が常に流出している相模湖で は，それを上回る増殖を示すときに細胞密度が高く なる。 ラン藻は， $29^{\circ} \mathrm{C}$ 以下では水温が高いほど増 殖率が高いため，相模湖では水温のピークとラン藻 の細胞密度のピークはおおむね一致している，1988 年以降，神奈川県では水温を下げるために湖に揚水 筒という筒をたて，筒の底から空気を注入すること で大きな泡を作り，この泡と一緒に湖底の泠たい水 を湖の表面に運ぶ「エアレーション」と呼ばれる装 置を導入した。その結果，エアレーション導入前は 7 月下旬から 8 月上旬にピークとなることが多かつ たのに対し，エアレーション導入後は水温上昇が遅 れ，ラン藻のピークは 8 月下旬になり，アオコ状態 の期間が短くなり， $10^{6}$ 細胞 $/ \mathrm{mL}$ を超えたのは 1997 年 8 月 28 日の 1 回に減少した。しかしなが ら，本装置の効果は持続せず，導入後の 10 年間よ り最後の 10 年間の方がアオコ状態の期間が増加傾 向であった。一方, 出現するラン藻の種類に関して は，通常細胞の小さいネンジュモ目（Nostocales） は細胞の大きい Dolichospermum より早く出現する が，1997 年は 8 月下旬に大発生し, 細胞の大きい Dolichospermum より遅く出現した。 8 月は Microcystis が優占することが多いが，9月中旬には

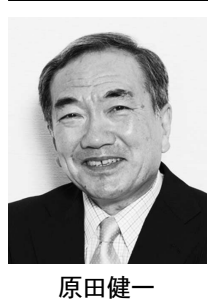

1971 年千葉大学薬学部製薬化学科卒, 73 年同大学院薬学研究科修士課程修了 後, 田辺製薬 (株) 発酵化学研究所, 76 年名城大学薬学部助手, 83 年薬学博士 (東北大学), 85 年名城大学薬学部講師, 85 年米国イリノイ大学化学科博士研究 員, 88 年名城大学薬学部助教授, 2002 年同大学院総合学術研究科及び薬学部 教授を経て 21 年同大学名誉教授. 


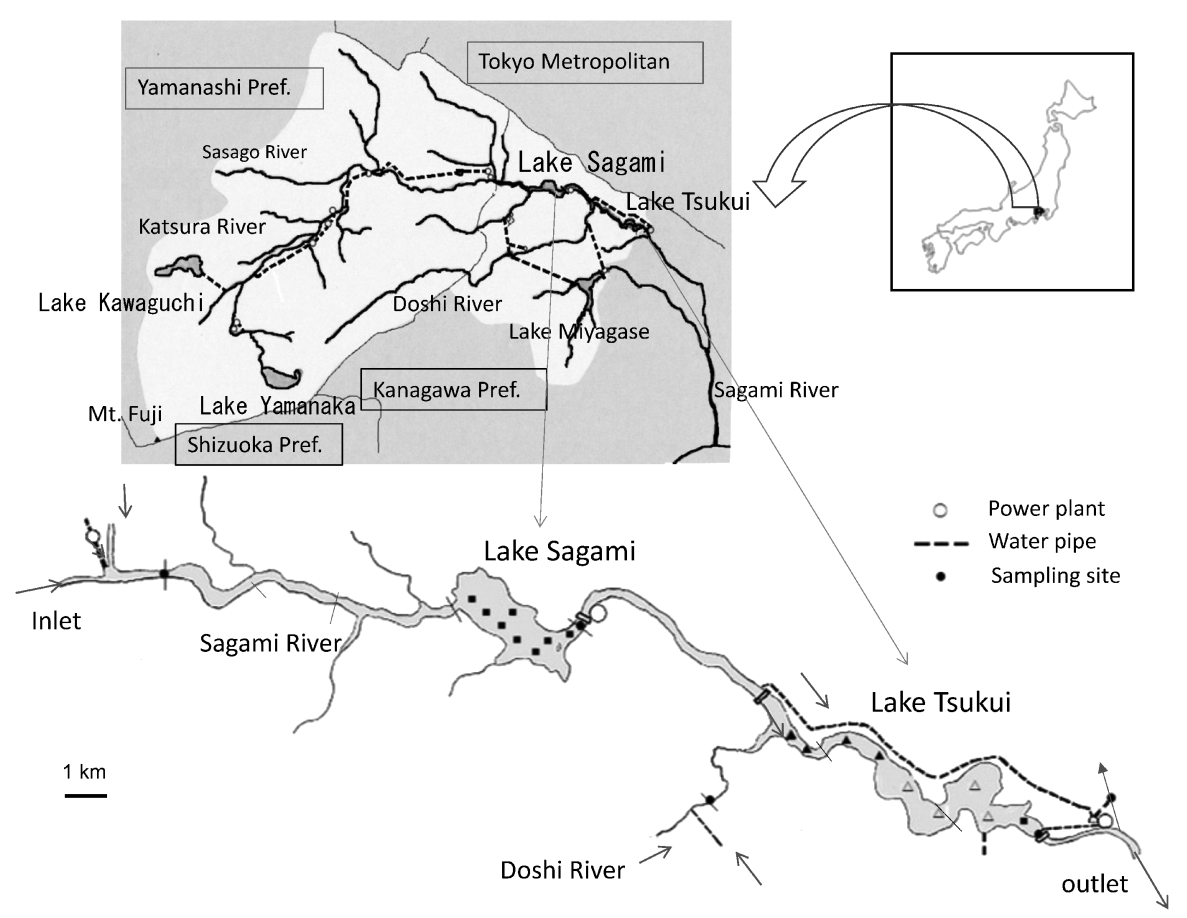

Fig. 2. Map of Lakes Sagami and Tsukui

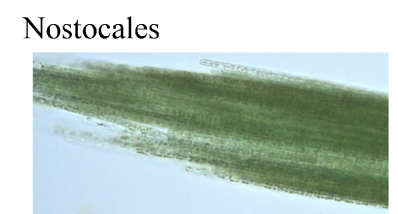

Aphanizomenon flos-aquae

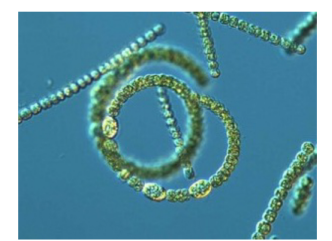

Dolichospermum crassum

Microcystis

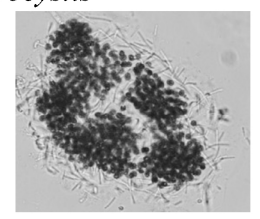

(M. aeruginosa)

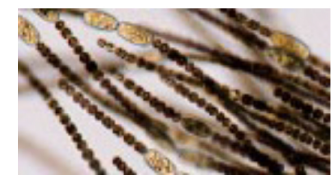

Dolichospermum affine

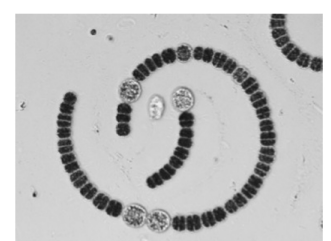

Dolichospermum mucosum

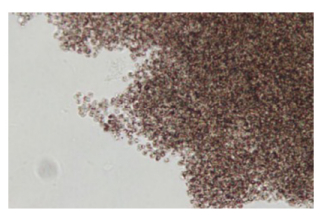

(M. ichthyoblabe)

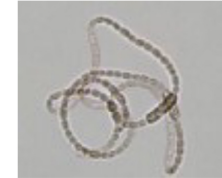

Dolichospermum mendotae

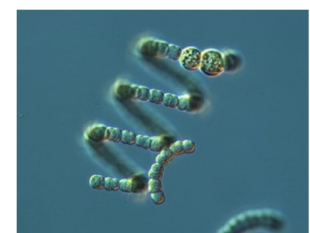

Dolichospermum ucrainicum

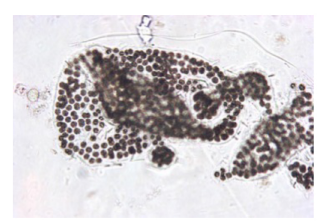

(M. wesenbergii)

Fig. 3. Micrographs of Several Cyanobacteria Appearing in Lakes Sagami and Tsukui (Color figure can be accessed in the online version).

水温躍層が弱くなり, 流出率が高くなつて減少し, 10 月上旬にはアオコ状態ではなくなった. ${ }^{3)}$

津久井湖においては流出がないため, 徐々に蓄積 し続けて細胞密度が高くなる。 そのため, 前期 (7493 年) の水温は相模湖同様 7 月から 8 月にかけて ピークとなったが, ラン藻は増殖率が下がっても蓄
積が続き，そのピークは 1994 年を除き 9 月上旬で あった. 2007 年 8 月下旬に Microcystis が $10^{7}$ 細胞/ $\mathrm{mL}$ に達し, 平均值の最大も $0.7 \times 10^{6}$ 細胞 $/ \mathrm{mL}$ と なった。また, Dolichospermum mendotae が最も 早く出現し， 5 月にアオコ状態となることもあっ た.さらに，7月には Aphanizomenon flos-aquae, 
D. affine, Microcystis が出現し, 細胞の大きい Dolichospermum は比較的少なく, 8 月中旬以降は Microcystis が優占した。 津久井湖は相模湖より水 温が高く，そのうえ擋拌水深の水量が多いために水 温が低下し難く，10 月上旬まで $20^{\circ} \mathrm{C}$ 以上あること が多く, 台風による流出がない限り，11月までラ ン藻がみられた. ${ }^{3)}$

2 つの連続したダム湖である相模湖及び津久井湖 の 40 年間（1974-2013 年）にわたる長期的記録の うち，生物的及び無生物的なパラメータである栄養 塩, 水温, 細胞密度及び水の滞留がラン藻類の動態 へいかに影響するかを評価した。これらのパラメー 夕の栄養塩のうち dissolved inorganic nitrogen （DIN）はいずれの地点でも充足していた. Soluble reactive phosphorous (SRP) は相模湖では過剩にあ り，常に利用できていた。一方，津久井湖において は，鉛直分布が変化し，利用性の変化による影響が みられたが，相模湖より濃度が低いにもかかわらず 出現量が多いことから, 出現量と優占種の変化には SRP の利用性への影響を含め，湖水の流れの影響 が大きいと考えられる. 最高水温として $23.5^{\circ} \mathrm{C}$ か ら $29^{\circ} \mathrm{C}$ まで観測されたが, この範囲では, ラン藻 の出現量と優占種の出現に影響はみられなかった.

また，エアレーションの導入により表層水温は約 $2^{\circ} \mathrm{C}$ 低下したが，これは上述の範囲内であった。最 もラン藻の出現量と優占種の出現に影響があったの は表層の滞留状況であり, 相模湖では通常ネンジュ モ目が優占するが, 表層が滞留し, 流出率が低いと きはMicrocystis が優占した。一方，津久井湖では 前期（74-93 年）の 20 年間では表層が完全に滞留 してラン藻が流出せず，集積を続けMicrocystis が 優占した. エアレーションを導入した後期でも流出 しないが, 表層のラン藻は分散し, ネンジュモ目が 優占したが，表層が特に滞留したときはMicrocystis が優占した。 したがって，気象条件やダム湖の 構造や付帯設備に基づく表層の帯留状況が「優占種 がネンジュモ目であるか Microcystis であるか」に 最も影響していることになる。これまで相模湖で 3 回，津久井湖で 4 回の溶藻現象が記録された，その うち, Microcystis がほとんど観察されなかった 2 回は湖面にできるラン藻の厚い膜状の浮かす（スカ ムと呼ばれる）が白濁し，Microcystis が $10 \%$ 以上 のときは青色化を伴った溶藻現象が生起した（Fig.

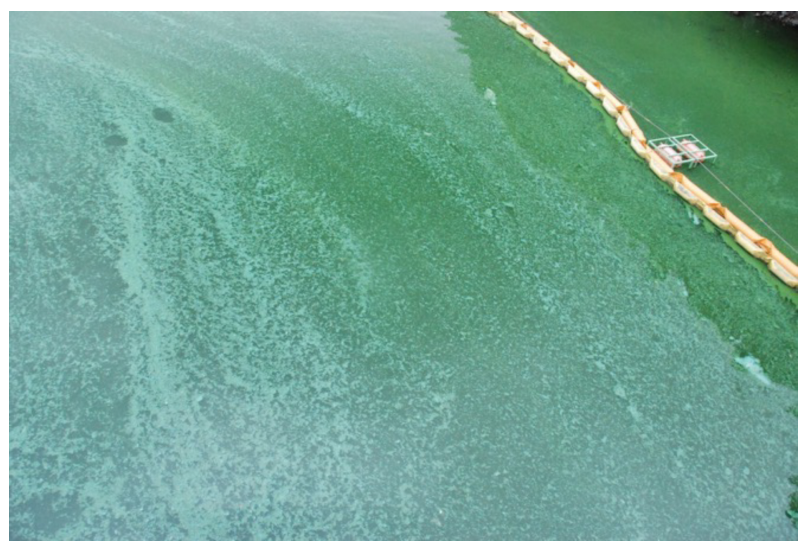

Fig. 4. Cyanobacteria with Blue Color Formation during Lysis in Lake Sagami

(Color figure can be accessed in the online version).

4). 溶藻現象は, Dolichospermum や Aphanizomenon が定点で $10^{6}$ 細胞 $/ \mathrm{mL}$ 程度の高密度のところで 生起していたが, 溶藻現象が起きた地点は定点より 高密度で, $10^{7}$ 細胞 $/ \mathrm{mL}$ に達していたと推察され た。しかし，ほとんどのラン藻が Microcystis のと きは溶藻現象が起き難く, 津久井湖定点で Microcystis が $10^{7}$ 細胞/ $\mathrm{mL}$ に達することがあった. Microcystis だけが $10^{6}$ 細胞 $/ \mathrm{mL}$ のときは, 激減す ることはなく，2 カ月以上続いたが， $10^{7}$ 細胞 $/ \mathrm{mL}$ では約 2 週間続いた後, 1 週間で $1 / 100$ 以下に減少 した. また, 溶藻現象の際に種組成の変化が起こり,

Dolichospermum やAphanizomenon は減少し, Microcystis が優占した. ${ }^{3)}$

1-3. 解明すべき問題点 各種生物的及び無生 物的な条件下, 湖沼生態系では種々の営みが行われ ている. 上述した 40 年間（1974-2013 年）の観察 から以下の 3 つの興味深い問題が提起された.

1） ラン藻類の増殖と減少

ラン藻の出現量と優占種の出現に最も影響があつ たのは表層の滞留状況であった。湖沼ではラン藻類 の増殖と減少はかならず生起するが, 従来から指摘 されていた照度, $\mathrm{pH}$, ガス胞, 増殖速度, 栄養, 水温などは決定打にはなっていないようである。そ れでは，表層の滞留状況で何が起きているのであろ うか (Fig. 1).

2）ラン藻類の溶藻と青色化を伴う現象とは 通常, 湖沼生態系で起きる現象は注意深い観察に よってのみ見い出される，上述したように，ラン藻 類の溶藻現象は多くは生起していないようである 
が，昨日まで真緑だったラン藻類が次の日には白濁 したり，あるいは青色化を伴って溶けていることは 極めて不思議である.これらの現象は今回の現場で ある相模湖・津久井湖ばかりではなく, 諸外国でも 報告されている。一体，何がこれらの現象の原動力 になっているのだろうか (Fig. 4).

\section{3） ラン藻類の種の季節遷移}

毎年, 湖沼生態系では数種のラン藻類が出現して は消失している，温帯に属している相模湖・津久井 湖では，初夏あたりから Aphanizomenon，そして Dolichospermum が出現し, 真夏から初秋には Microcystis が現れ，10 月頃には消失する．このラ ン藻類の種の季節遷移には再現性がありそうであ る。これらの遷移をどのように考えればいいのだろ うか (Fig. 3).

本総説では，神奈川県の相模湖・津久井湖で 1974 年以来 40 年間観察されてきたアオコ形成に関 する現象を扱う。従来，これらの現象は照度，

$\mathrm{pH}$, ガス胞, 増殖速度, 栄養や水温などの因子に よるとされてきたが，筆者の研究結果からは他の因 子を導入しなければ解決できないことが示唆され た．偶然にも，ラン藻由来の溶藻活性化合物を発見 したことにより，「ラン藻が産生し，自らを溶藻す る本化合物を研究の中心に据え」, 湖沼で生起する 諸現象との関連を調査するものである，具体的に は，ラン藻自身が産生する揮発性有機化合物 (volatile organic compound; VOC) を指標とする化 学生態学的手法により湖沼生態系におけるラン藻が 関与する諸現象の解明を試みる.

\section{2. ラン藻類からの VOC の検出と溶藻性}

2-1. ラン藻類からの VOC の検出＼cjkstart湖沼生態 系では多くの微生物が相互作用しており，当然ラン 藻を消滅させる微生物も存在している，筆者たちは 溶藻性のためのスクリーニング法を確立させ, ${ }^{4)}$ 相 模湖や津久井湖の水関連試料から溶藻性微生物の探 索を行った。今回の実験において 11 種の活性のあ る細菌を見い出したが，これらはほとんどが自然界 にありふれて存在する Bacillus 属類であった。抗う ン藻活性のあつた 8 種（B-1-B-8）のうちの 1 つで ある B-1A 株は，相模湖の底泥より単離されたグラ ム陽性の好気性桿菌であり, 最終的に遺伝研アク セッション番号 D78460 Brevibacillus formosus と 98.512\%の相同性を示したことから，Brevibacillus sp. と同定された。引き続いて，B-1A 株の培養を 行い，その培養液を ODS カラムによる分画を行っ た.しかし，活性化合物を見い出すことはできず， 本細菌が産生する活性化合物は, ODS カラムによ る分画では単離困難であった。 Wright らは, Bacillus sp.により産生される VOC が，ラン藻（主 に Anabaena 属) の成育を阻害することを報告して いる. 6,7) そこで, B-1A 株の溶藻性は揮発性物質に 起因する可能性を考慮し， GC/MS を用いて B-1A 株及びラン藻懸濁液中に含有される揮発性化合物を 探索することとした。実際には，GC/MS により以 下に示した 4 種の試料（試料 $\mathrm{a}, \mathrm{b}, \mathrm{c}$ 及び d）を解 析した。なお, 桜井培地は細菌類の培養のための培 地である. ${ }^{8)}$ その結果, 桜井培地（試料 a）と B-1A 株培養液 (試料 b) を比較して B-1A 株からは，ピー ク（1）を特異的に検出した。 また，National Institute Environmental Study（NIES）-102 ラン藻懸濁 液（試料 c) と B-1A 株をラン藻に添加したラン藻 懸濁液（試料 d）を比較して，共存培養によりピー ク（2）及び生成量が増加したピーク（3）を検出し たが，B-1A 株由来ピーク（1）は検出されなかつ た。ピーク（1）は，GC/MS における保持時間及 びマススペクトル解析より 8-methyl-2-nonanone と 推定した。 また，ピーク（2）及び（3）のマススペ クトルをデーターベースに照合した結果，ピーク （2）は 3-methyl-1-butanol, ピーク（3）は $\beta$-cyclocitral であると同定した (Fig. 5).9 ${ }^{9}$ これらの揮 発性化合物のうち 3-methyl-1-butanol は, Wright らの報告によりラン藻溶藻活性を持つVOCである ことが明らかとなっており, ${ }^{7)} \beta$-cyclocitral は, Jüttner らが Microcystis 属から検出される揮発性化合

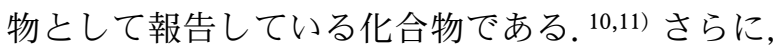
被検ラン藻 NIES-73, 103, 112, 298 株に対しても, 同様に B-1A 株共存培養 3 日目の培養液を $\mathrm{GC} / \mathrm{MS}$ 分析したところ，すべての被検ラン藻から $\beta$-cyclocitral が検出され，3-methyl-1-butanol は NIES73 以外のラン藻株において検出された.

\section{2-2. ラン藻類由来 VOC の溶藻活性 B-1A 株} が溶藻性を示すにもかかわらず，活性本体を単離す ることはできなかったが，ラン藻自身からは $\beta$-cyclocitral や 3-methyl-1-butanol が検出された。 既に 示したように, B-1A 由来の溶藻性を追跡すると, その比活性は精製を進めるに従って減少する。 それ 


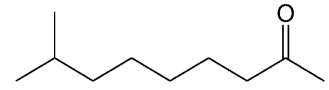

(1) 8-methyl-2-nonanone

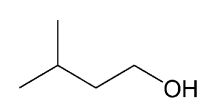

(2) 3-methyl-1-butanol

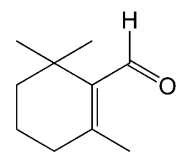

(3) $\beta$-cyclocitral

Fig. 5. Structures of Volatile Organic Compounds (VOC) Derived from Microcystis aeruginosa NIES-102 Reproduced with permission from Chemosphere, 71(8), 1531-1538 (2008). Copyright 2008 Elsevier.

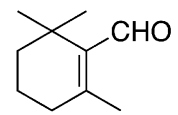

$\beta$-cyclocitral<smiles>OCCc1ccccc1</smiles>

2-phenylethanol 2-methyl-1-butanol 3-methyl-1-butanol

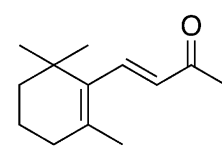

-ionone<smiles>CC[C@H](C)CO</smiles>

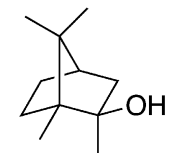

2-methylisoborneol
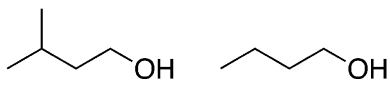

1-butanol

Fig. 6. Structures of Volatile Organic Compounds (VOC) from Cyanobacteria

を考慮するとラン藻自身が生産する揮発性化合物が 上述した溶藻性に関与していると推察された。 そこ で, NIES-102 株を被検ラン藻として，ラン藻が産 生する VOC, $\beta$-cyclocitral, $\beta$-ionone, 2-methyl-1butanol, 3-methyl-1-butanol, 2-phenylethanol, 1butanol, geosmin 及び 2-methylisoborneol (2-MIB) の溶藻性を調べた (Fig. 6).クロロフィル吸光度測 定法により $\beta$-cyclocitral 及び $\beta$-ionone の添加量を それぞれ 0.01, 0.1, $1 \mathrm{~mL}$ としたときの溶藻性の検 討を行った. $\beta$-Cyclocitral を $1 \mathrm{~mL}$ 添加した $65 \mathrm{mM}$ 溶液では添加 30 分後に懸濁液の色調が鮮やかな青 色に変化し, $0.1 \mathrm{~mL}$ 添加した $6.5 \mathrm{mM}$ 溶液では 1 時間後に青色に変化した。 その後, 1 日以内に溶藻 は完了し，白濁した。しかしながら， $0.01 \mathrm{~mL}$ 添加 溶液では溶藻活性は観察されなかった。一方,

$\beta$-ionone は $0.01 \mathrm{~mL}$ 添加した $0.5 \mathrm{mM}$ 溶液でも溶 藻が観察され，いずれの濃度においても添加 6 時間 後に黄緑色を呈し，その後白濁し，一日で溶藻が完 了した．結果的に，添加した化合物によって懸濁液 の色調が異なる溶藻現象が観察された。 ${ }^{9)} \beta-\mathrm{Cy}-$ clocitral による特徵的な青色化現象は非常に興味深 $<$, chlorophyll $a$ 及び $\beta$-carotene が分解し, phycocyanin による色が現れたものと考えられた. $\beta$-Cyclocitral は Microcystis 属ラン藻が産生する揮 発性の化合物であり, ${ }^{11,12)}$ 本化合物は緑藻類の Chlorella pyrenoidosa の成長阻害作用を持つことが
Ikawa らにより報告されている.13) 3-Methyl-1butanol は $0.058 \mathrm{~mL}$ 添加した $6.5 \mathrm{mM}$ 溶液では溶 藻活性は観察されず，0.58 $\mathrm{mL}$ 添加した $65 \mathrm{mM}$ 溶 液において 4 日間かけて徐々に溶藻が進行した。同 時に行った $6.5 \mathrm{mM} \beta$-cyclocitral 添加液と比べて 10 倍以上溶藻活性が低かった。また，最大濃度が $2 \mathrm{mM}$ ( $\beta$-cyclocitral の溶藻活性評価濃度の 3 分の 1 ) の geosmin と2-MIB ${ }^{10,12)}$ では添加直後から懸濁液 の色調が変化し, $\beta$-cyclocitral や $\beta$-ionone よりも急 速に溶藻が進行し，添加後 6 時間で chlorophyll $a$ の吸収を消失することを確認した．最も溶藻の進行 が早かったのは geosmin で，つぎに 2-MIB であっ た。以上の結果から，最も低濃度で溶藻活性が観察 されたのは $\beta$-ionone で, $0.01 \mathrm{~mL}$ 添加した $0.5 \mathrm{mM}$ 溶液であった。逆に，3-methyl-1-butanol は溶藻活 性が低く, $65 \mathrm{mM}$ 溶液で溶藻活性が観察された。

$\beta$-Cyclocitral は $0.1 \mathrm{~mL}$ 添加した $6.5 \mathrm{mM}$ 溶液で溶 藻活性が確認され，懸濁液の色調が青色に変化する 特徵的な溶藻現象が観察された. ${ }^{9)}$

2-3. 溶藻活性と疎水性ここれまで述べた結果 から，ラン藻が産生する揮発性化合物によって自身 が溶澡することが明らかとなつた。これらの化合物 は揮発性を有する低分子化合物であることから，こ れら溶藻活性に関与する因子として疎水性が溶藻現 象を生起すると推察した。 そこで, 同様の性質を有 し，抗菌活性を有することが報告されているテルペ 
<smiles>Cc1ccc(C(C)C)cc1O</smiles>

carvacrol<smiles>O=C/C=C/c1ccccc1</smiles>

cinnamaldehyde<smiles>CC(C)=CCCC(C)=CC=O</smiles>

citral

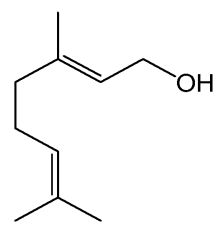

geraniol<smiles>C=CC(C)(O)CCC=C(C)C</smiles>

linalool<smiles>CC(C)[C@H]1CC[C@@H](C)C[C@H]1O</smiles>

menthol

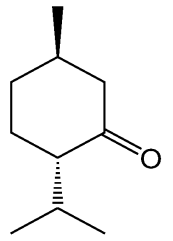

menthone

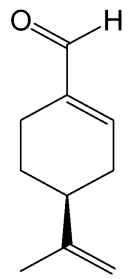

perillaldehyde<smiles>Cc1ccc(C(C)C)c(O)c1</smiles>

thymol<smiles>COc1cc(C=O)ccc1O</smiles>

vanillin

Fig. 7. Structures of Terpenoids from Plant

Reproduced with permission from Chemosphere, 71(8), 1531-1538 (2008). Copyright 2008 Elsevier.

ノイド14-16)が溶藻性を示すか否かを検討した。今 回，実験に用いた化合物はアルデヒド基，アルコー ル性水酸基，フェノール性水酸基，ケトン基を有す る植物性テルペノイド（Fig. 7）である. Table 1 にはこれらの化合物の疎水性を数值化した分配係数 $\log D$, 分子量 (M. W.) 及び minimum inhibitory concentration（MIC）をまとめた。 $\log D$ 值は水と 1-octanol 間の $\mathrm{pH}$ 依存分配係数の対数で，しばし ば疎水性のパラメーターとして使用されてい る. ${ }^{17,18)}$ つぎに, 溶藻活性の尺度となる MIC を求 め，物理化学的性質と溶藻活性の間に相関関係があ るかを考察した。 さらに， $\beta$-cyclocitral を添加した 際に観察された青色化現象を示す化合物があるか否 かを調べるために，溶藻時の懸濁液の色調変化の観 察も併せて実施した．疎水性数值 $\log D$ は酸解離定 数（p $\left.K_{\mathrm{a}}\right)$ を考慮したものであり，ここでは溶藻活 性の評価を行うにあたり，MA 培地2)への添加が想 定されたため $\mathrm{pH} 8.6$ における值を用いた。数值は 大きいほど疎水性が高く，小さいほど親水性が高い ことを示している。テルペノイドの $\log D$ 值は 0.31 から 4.39 の間に分布し，最も疎水性が高い化 合物は $\beta$-ionone で，つぎに geosmin，ついで geraniol 及び linalool であった，逆に，最も疎水性の 低い化合物は vanillin，ついで 3-methyl-1-butanol, cinnamaldehyde の順であった。これらの化合物の 分子量は 88.15 から 192.30 の間に分布し，最も大 きい化合物は $\beta$-ionone で，つぎに geosmin であっ
Table 1. $\log D$, Molecular Weight (M. W.) and Minimum Inhibitory Concentration (MIC) of Terpenoids and Volatile Organic Compounds (VOC) from Cyanobacteria

\begin{tabular}{lccc}
\hline \hline & $\log D$ & M. W. & MIC $(\mathrm{mM})^{\mathrm{a}}$ \\
\hline$\beta$-ionone & 4.39 & 192.30 & 2.5 \\
geosmin & 3.84 & 182.30 & 3.0 \\
geraniol & 3.28 & 154.25 & 0.6 \\
linalool & 3.28 & 154.25 & 2.5 \\
thymol & 3.28 & 150.22 & 0.15 \\
carvacrol & 3.27 & 150.22 & 0.15 \\
$\beta$-cyclocitral & 3.26 & 152.23 & 2.0 \\
menthol & 3.20 & 156.27 & 2.5 \\
citral & 3.17 & 152.24 & 0.6 \\
2-MIB & 2,77 & 168.28 & 2.5 \\
perillaldehyde & 2.68 & 150.22 & 0.6 \\
menthone & 2.63 & 154.25 & 5.0 \\
cinnamaldehyde & 2.12 & 132.16 & 0.15 \\
3-methyl-1-butanol & 1.22 & 88.15 & 200 \\
vanillin & 0.31 & 152.15 & 0.3 \\
\hline
\end{tabular}

a These were obtained using NIES-102 strain. Reproduced with permission from Chemosphere, 71 (8), 1531-1538 (2008). Copyright 2008 Elsevier.

た.これは $\log D$ 值の高い順とも一致した。逆に,

最も小さい化合物は 3-methyl-1-butanol であった (Table 1). 同一条件下で算出された MIC 值を比較 すると最も溶藻活性が高かった化合物は植物テルペ ノイド thymol, carvacrol, 及び cinnamaldehyde で，ラン藻由来揮発性化合物の 10 倍低濃度で発育 阻害を示した。 ラン藻由来揮発性化合物の MIC 值 はほぼ等しく, $2.5 \mathrm{mM}$ 前後であったが 3-methyl-1- 
butanol は他と異なり, 著しく高濃度であった。 ク ロロフィル吸光度測定法による溶藻活性評価におい て, ラン藻由来揮発性化合物では最も活性が高く, $2 \mathrm{mM}$ で急速な溶藻を示した geosmin の MIC 值は $3 \mathrm{mM}$ と 2-MIB のそれより高い值を示した。一 方, 植物テルペノイドの MIC 值は様々な数值を示 し，フェノール性水酸基やアルデヒド基を有する化 合物の活性が高く，アルコールやケトン基ではやや 活性が低い傾向にあった。 官能基が活性に関与して いるとされているが, ${ }^{19)}$ ラン藻由来揮発性化合物に はこの傾向が当てはまらなかった，さらに，使用し たテルペノイドの $\log D$ 值と MIC 值との間に相関 性があるか確認したところ, 相関係数 $\mathrm{r}=-0.439$ であり，両者の間に相関関係は成立しないと考えら れた。

\section{2-4. ラン藻由来アルコール類上述したよう} に, ラン藻由来揮発性化合物には $\beta$-cyclocitral や $\beta$ iononeばかりではなく 3-methyl-1-butanol ようなア ルコールも存在していた（Fig. 6). Microcystis 属 の産生するアルコール類が酵母の産生するアルコー ル類20-22) と同様に 2-keto-acid decarboxylase (KDC) 由来であることを明らかにするため, 全ゲノムの解 明された NIES-843 を用いて KDC に相当する遺伝 子を探索したところ, 目的遺伝子が確認され， MaKDC と名付けた。 この MaKDC を大腸菌へ挿 入し，生成物を探索したところ，MaKCD 挿入大腸 菌より, 2-methyl-1-butanol 及び 3-methyl-1-butanol だけでなく, 新たに2-phenylethanol も検出され, 産生量は 2-phenylethanol > 3-methyl-1-butanol >2methyl-1-butanol であった。したがって, MaKCD は 2-methyl-1-butanol, 3-methyl-1-butanol 及び 2phenylethanol の生成に関与していることが示され た. ${ }^{23)}$ そで，大量に培養した MaKDC 発現大腸菌 から酵素である MaKDC を精製した後, 2-keto-4methylpentanoate, 2-ketomethylvalerate, 2-ketoisovalerate, phenylpyruvate, pyruvate 及び indole-3pyruvate の 6 種の 2-ケト酸を基質として, MaKDC の脱炭酸活性を測定した。その結果，2-keto-4methylpentanoate, 2-ketomethylvalerate, 2-ketoisovalerate 及び phenylpyruvate は，それぞれ3methyl-1-butanol, 2-methyl-1-butanol, isobutanol 及 び 2-phenylethanol へと変化し, 脱炭酸活性が確認 された。また，これらの基質に対する活性の強さは 2-keto-4-methylpentanoate $>$ phenylpyruvate $>2$ ketomethylvalerate $>$ 2-ketoisovalerate の順であり, MaKCD 扱入大腸菌における産生実験とは異なる結 果となった。これは, MaKDC としては2-keto-4methylpentanoate に対する活性が最も高いが, 生体 から産生される場合, 他の環境的な要因が影響して いるためであると考えられた，キラルカラムを用い た Microcystis 属の産生する 2-methyl-1-butanol の 絶対配置の確認を行つたところ, $(S)$ - (-)-2-methyl1-butanol と決定され，L-isoleucine と同様の絶対配 置を持つことが明らかとなった（Fig. 6). 以上の ことから, Microcystis 属の産生するアルコール類 は MaKDC 由来であることが明らかとなった. ${ }^{23)}$

Microcystis 属の産生する 2-methyl-1-butanol, 3methyl-1-butanol 及び 2-phenylethanol などのアル コール類の役割を明らかにするために, Microcystis 属の成長, 培地に含まれる硝酸態窒素の推移及び産 生されるアルコール類の挙動を比較した。その結 果, アルコール類は Microcystis 属の培養における 死滅期後期に大量に産生されており，そのとき，培 地中の硝酸態窒素はすべて消費されていた。さら に, 自然界においてもMicrocystis 属が大量に発生 し, 溶藻が引き起こされている状況において, 大量

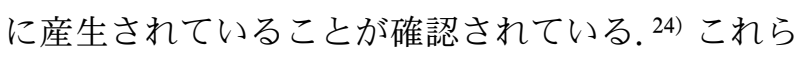
のことから, 2-methyl-1-butanol, 3-methyl-1-butanol 及び 2-phenylethanol などのアルコール類は老 化若しくは環境の悪化したときに産生され， Microcystis 属の生活環に関与していることが考え られた。また，2-phenylethanol は本実験によって 初めて Microcystis 属からの産生が明らかにされ, さらにアルコール類の中で最も多く検出されたこと から, Microcystis 属の生活環に対し重要な役割を 担っていることが示唆された.

\section{2-5. ラン藻類由来の VOC による溶藻形態}

Microcystis 属由来揮発性化合物 $\beta$-cyclocitral 之 $\beta$-ionone 及び Anabaena 属や Oscillatoria 属が産生 するカビ臭化合物の geosmin や 2-MIB によってラ ン藻自身が溶藻することが判明している。 一体どの ようにして細胞を破壊しているのか，水及びメ夕 ノールを加えたものを陰性コントロールとして，ラ ン藻由来揮発性化合物による溶藻時の細胞形態変化 を走査型電子顕微鏡により観察し，比較を行うとと もにクロロフィル吸光度測定法も併せて実施した. 
陰性コントロールの水及びメタノール中では，50 時間以上経過しても細胞表面が滑らかであったのに 対し， $6.5 \mathrm{mM}$ 濃度の $\beta$-cyclocitral 及び $\beta$-ionone に おける形態変化は添加後 1 時間程度でしわが形成さ れ，縮小している様子が観察された。また，クロロ フィル吸光度測定法により得られる chlorophyll $a$ 量の減少よりもラン藻細胞の形態変化が先に起こる ことが判明した。このことから，揮発性化合物を細 胞の外側から加えた場合, 細胞膜若しくは細胞膜を 通して細胞内へ傷害を与え, chlorophyll $a$ 量が減 少することが示唆された。さらに，培養を続けて 15 時間ほど経過し, chlorophyll $a$ がほとんど検出 されなくなる頃には細胞は壊れて凝集し, 残骸の塊 となっている像が観察された。結果的に， $\beta$-cyclocitral 及び $\beta$-ionone による形態変化はしわ型を 示した. ${ }^{25)}$ 種々の官能基を有する植物性テルペノイ ドでアルデヒド基を有する perillaldehyde 及びアル コール性水酸基を有する linaloolによる溶藻時の形 態変化を観察した。これらは形態変化を示すまでの 時間はラン藻由来揮発性化合物より遅い傾向にある が, perillaldehyde は試薬添加後 2 時間で細胞表層 全体の剥離が観察され，linalool は9 時間で細胞表 面の一部が剥ぎ取られたような変化が観察された。

一方，アミノ酸である $\beta$-cyano-L-alanine や L-lysine ${ }^{26,27)}$ ではその形態変化にはしわ型は認めら

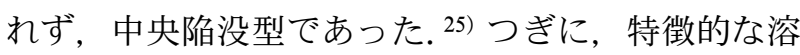
藻性を示した $\beta$-cyclocitral 及び L-lysine を作用さ せ, 透過型電子顕微鏡を用いてその細胞内小器官の 変化を観察した。 その結果， $\beta$-cyclocitral は細胞膜 全体に作用し，穴が空いた様子が観察された．細胞 内のチラコイド膜は残存しており，フィコビリソー ム顆粒が細胞中心部に多く観察された。このことか ら, 細胞膜に傷害を与える植物テルペノイドとは異 なり， $\beta$-cyclocitral では細胞内部で中心に集まって いたフィコビリソーム顆粒若しくはそれ以外の器官 へなんらかの作用を与えていることが推察された。

一方， L-lysine は細胞壁及び細胞膜の一点に作用 し, チラコイド膜は残存した状態で, その他の小器 官が消失していた. ${ }^{25)}$

\section{3. $\beta$-Cyclocitral による青色化を伴う溶藻現象と 呈色機構}

3-1. 青色化現象 ラン藻類は自身の増殖過程 で産生する芳香性化合物の $\beta$-cyclocitral や $\beta$-ionone
及びカビ臭物質の geosmin や 2-MIB などの揮発性 有機化合物により溶藻することが判明した。その 際，ラン藻は緑色から黄緑色を経て白色へと変化し たが， $\beta$-cyclocitral の場合にのみ，極めて特徵的な 青色を呈した後，白濁することが確認された. ${ }^{9,28)}$ しかしながら, 化学的性質が類似した植物由来の揮 発性化合物を用いた溶藻過程ではこのような青色化 現象は観察されなかったことから， $\beta$-cyclocitral が 自然界で生起する溶藻現象に深く関与していると推 測された。この仮説を証明するためラン藻に $\beta$-cyclocitral 及び比較対照として $\beta$-ionone を添加した 際の変化を詳細に観察した。一般に，ラン藻細胞は 吸収波長の異なる 3 種の光合成色素, chlorophyll $a, \beta$-cyclocitral 及び phycocyanin を有しており，青 色化現象はこれらの色素が溶藻により培養液中に溶 出し, 光などにより分解することにより引き起こさ れていると考察された。 NIES-102を被検ラン藻と して, $\beta$-cyclocitral 又は $\beta$-ionone を添加し，紫外可 視分光光度法により培養液中の光合成色素の消長を 追跡した. 添加前の被験ラン藻懸濁液を測定すると, $420 \mathrm{~nm}$ と $680 \mathrm{~nm}$ 付近に chlorophyll $a$ のピーク を，また $500 \mathrm{~nm}$ 付近に $\beta$-carotene のピークを，さ らに $620 \mathrm{~nm}$ 付近に phycocyanin のピークが出現す る. $\beta$-Cyclocitral 添加によって青色を示すとき, 添 加前に存在した chlorophyll $a$ と $\beta$-carotene のピー クが消失し， $615 \mathrm{~nm}$ 付近のピークのみが残存して いた。一方， $\beta$-ionone を添加したものは，特定の ピークが先に消失する現象はみられず，同一の割合 で各ピークの減少が観察された。水を添加した場合 には，その特徵的なスペクトルパターンを保ったま ま吸光度が徐々に増加し，ラン藻が増殖しているこ とを示している. ${ }^{28)}$ 以上の結果, $\beta$-cyclocitral 添加 による培養液の青色化現象は，青色色素の phycocyanin に由来すると結論される。すなわち， phycocyanin は chlorophyll $a$ よりも $\beta$-cyclocitral に 対して安定であり， $\beta$-cyclocitral を添加すると chlorophyll $a$ が phycocyanin よりも先に消失するこ とを示している。一方, $\beta$-ionone は $\beta$-cyclocitral の ように, chlorophyll $a$ や $\beta$-carotene を特異的に分 解する能力は有しておらず， 3 種の色素を同様に分 解していく．すなわち， $\beta$-cyclocitral を添加した場 合，その直後では懸濁液表面に油滴が観察されるが 2 時間ほど経過すると油滴は消失した。一方, $\beta$-io- 


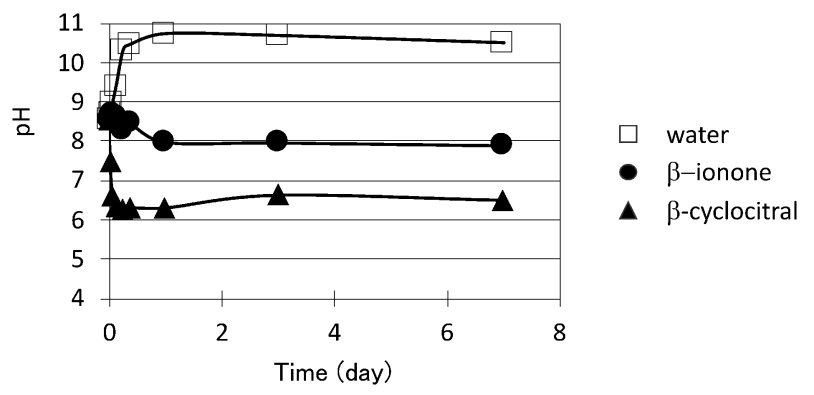

Fig. 8. $\mathrm{pH}$ of the Resulting Solution Added with $\beta$-Cyclocitral and $\beta$-Ionone

Reproduced with permission from J. Chem. Ecol., 35(11), 1295-1301 (2009) . Copyright 2009 Springer.

none を添加した場合には油滴の消失は観察されな かった。おそらく,この挙動の違いが， $\beta$-cyclocitral と $\beta$-ionone の chlorophyll $a へ$ 挙動の違 いに反映しており，特に $\beta$-cyclocitral が親水性の化 合物に変化していることを示唆している. ${ }^{28)}$

3-2. 培養液の酸性化 被験ラン藻に $\beta$-cyclocitral を添加し, 一定時間経過後の $\mathrm{pH}$ を測定し たところ，いずれの株においても直後から $\mathrm{pH}$ の低 下が起き，添加から約 3 時間で $\mathrm{pH} 5.5$ 付近まで低 下した。一方， $\beta$-ionone を添加したものでは $\mathrm{pH} の$ 顕著な低下は起きず，溶藻後も $\mathrm{pH} 8.0$ 付近を維持 した.コントロールとして水を添加したものでは, $\mathrm{pH}$ は逆に上昇した。これはラン藻の成長に伴い, 盛んに行われる光合成によって水中の二酸化炭素が 消費されたためである. ラン藻に $\beta$-cyclocitral を添 加すると $\beta$-ionone 又はコントロールとしての水を 添加したときと比較して明らかに $\mathrm{pH}$ が低下した (Fig. 8) が，その $\mathrm{pH}$ は Huang らの報告の值（pH 3.6 以下で溶藻）よりかなり高かった. ${ }^{29)}$ また， $\beta$ ionone 添加時では溶藻は起こるにもかかわらず $\mathrm{pH}$ の低下が起きなかったことから，溶藻と青色化現象 は同一の機構で生起していないと考えられた．以上 述べてきた結果から， $\beta$-cyclocitral のアルデヒド基 が水溶液中でカルボキシル基へと変化し，結果的に 反応液が酸性を示すと推察された。そこで，水又は MA 培地にアルデヒド基を有する化合物を添加し， $\mathrm{pH}$ 変化を追跡した。 $\beta$-Cyclocitral を添加した場 合，水中においても，緩衝能のある培地中でもその 直後から pH の低下が起こり，安定するまでに時間 は必要であったが, $\mathrm{pH} 4$ 前後まで低下し，その後 はほぼ一定となった。水に cinnamaldehyde を添加
した場合， $\beta$-cyclocitral と同程度の酸性を示したが, MA 培地中では $\mathrm{pH}$ 低下を示さなかった. Perillaldehyde を水に添加した際，直後からの急激な $\mathrm{pH}$ 変化は認められなかったものの，徐々に低下し，19 時間後には $\mathrm{pH} 4$ と酸性溶液となったが，やはり MA 培地中では酸性を示さなかった。Citral 及び vanillin を水に添加した場合 $\mathrm{pH} 8$ から $\mathrm{pH} 6$ にまで 低下したものの，培地中で $\mathrm{pH}$ が低下したものは vanillinのみであった。以上の結果から， $\beta$-cyclocitral は他のアルデヒド体とは異なり，極めて特 徵的な挙動を示すことが示された。すなわち，培養 液に添加した際にはその直後から bicine の緩衝作 用を超えるほどの酸性化合物に変換されていること が明らかとなった。結果的に，生成した酸性化合物 による急激な $\mathrm{pH}$ 低下によって chlorophyll $a$ は分 解され, phycocyanin が顕在化し，結果的に懸濁液 の青色化が生起したことになる. ${ }^{28)}$

\section{3-3. $\beta$-Cyclocitral の酸化機構 水溶液に $\beta$-cy-} clocitral を添加するとその水溶液の $\mathrm{pH}$ が急激に低 下した。このことから疎水性で油状物質の $\beta$-cyclocitral は水に添加直後から水溶性の酸性化合物へ と変化することが示唆され，溶藻や青色化には $\beta$ cyclocitral そのものではなく, 水との反応後に生じ た酸性化合物が関与していると推測された。そこ で，生成する酸性化合物の同定を試みた．まず，水 に $\beta$-cyclocitral を添加して鮮やかな青色を呈する 20 時間経過した水溶液から酸性及び中性・塩基性 化合物を分画した。酸性画分から得られた生成物を LC/MS 及び NMR によりスペクトル分析を行っ た。 その結果, $\beta$-cyclocitral を水に添加すると直ち に酸化を受けてカルボン酸となり, 分子量 168 の酸 性化合物，2,6,6-trimethylcyclohexene-1-carboxylic acid ( $\beta$-cyclocitric acid) が生成することが判明し た。結果的に，水中における $\beta$-cyclocitral より $\beta$-cyclocitric acid への酸化はなんら酸化剂を添加し なくても容易に進行することが判明した. ${ }^{30)}$ 一体, どのような経路で酸化されるのか，また上述したよ うに $\beta$-cyclocitric acid だけではなく複数の生成物の 存在が示唆された。これらを明らかにする目的で, $\beta$-cyclocitral を水に添加した後, その酸化挙動を $\mathrm{GC} / \mathrm{MS}$ を用いて調査した。まず， $\beta$-cyclocitral を 水に添加した後， $0,1,3,5,10,24$ 及び 72 時間毎に 培養液を採取した。採取した試料の $\mathrm{pH}$ を測定後, 


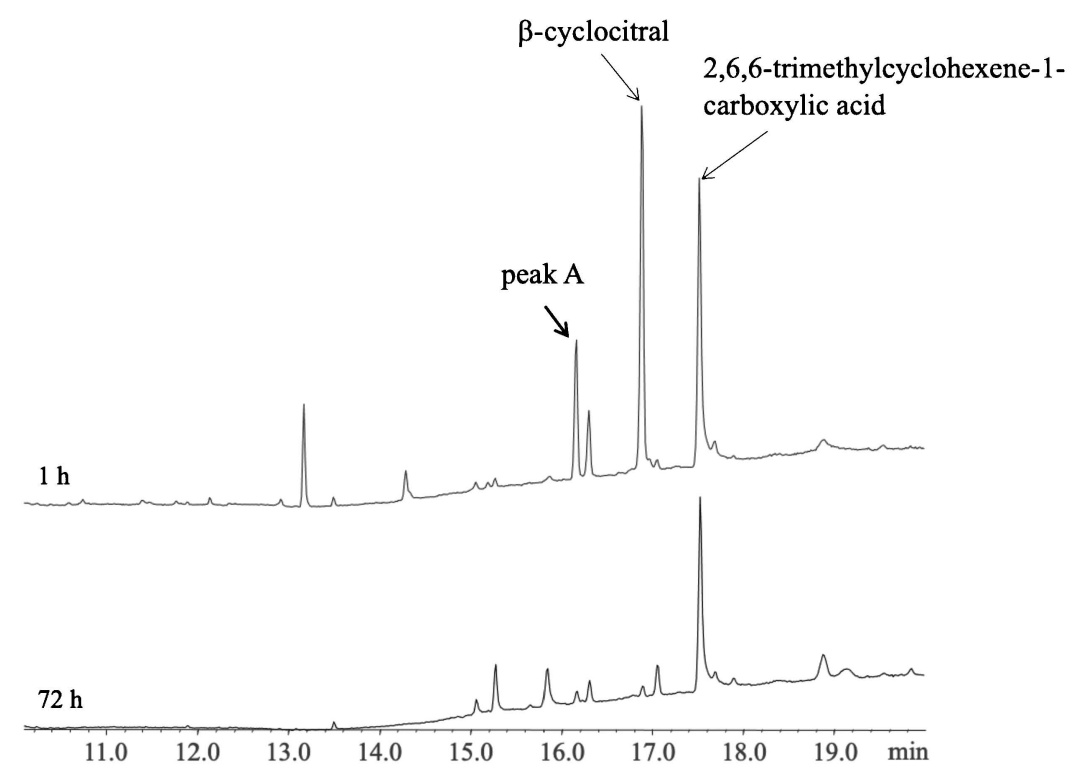

Fig. 9. GC/MS Chromatograms of the Reaction Products of $\beta$-Cyclocitral with Water after 1 and 72 Hours Reproduced with permission from Environ. Sci. Pollut. Res., 23(12), 11998-12006 (2016). Copyright 2016 Springer.

$\mathrm{Et}_{2} \mathrm{O}$ 抽出し, 得られた $\mathrm{Et}_{2} \mathrm{O}$ 層の $\mathrm{GC} / \mathrm{MS}$ 分析を 行った。その結果, $\beta$-cyclocitral 添加 1 時間後には, $\beta$-cyclocitral 及び $\beta$-cyclocitric acid 以外に出発原料 由来の peak A のピークが確認され， $\beta$-cyclocitric acid 以外のピークは 72 時間後にほぼ消失していた (Fig. 9). Peak A の EI マススペクトルを確認した ところ, 分子イオンである $m / z 168$ 以外に, フラ グメントイオンとして $m / z$ 153, 140 及び 125 が確

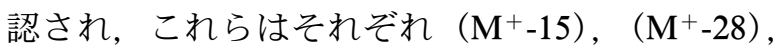
$\left(\mathrm{M}^{+}-43\right)$ と考えられ, peak $\mathrm{A}$ は $\beta$-cyclocitral の工 ノールエステル体である 2,6,6-trimethylcyclohex-1ene-1-yl formate であると推定された。本化合物の 同定は別途調製した標準品及びその ${ }^{1} \mathrm{H}-\mathrm{NMR}$ スペ クトル及び高分解マススペクトルにより，2,6,6trimethylcyclohex-1-ene-1-yl formate であることを 確認した。得られたエノールエステル体の構造確認 及びその安定性を調べるために, GC/MS 分析を用 いて本化合物の各 $\mathrm{pH}$ における安定性を調べた。 そ の結果，本化合物は酸性及び中性下では安定であっ たが，アルカリ性下においては 2,2,6-trimethylcyclohexanone 乞と分解され，24 時間後には開始時の ほぼ半分の量に減少していた。 ${ }^{30)}$ 以上の結果から, $\beta$-cyclocitral の水中での酸化は Baeyer-Villiger 型で 進行し, 主に $\beta$-cyclocitric acid と 2,6,6-trimethylcyclohex-1-en-1-yl formate を与えることが示された (Fig. 10).
3-4. 相模湖における青色化を伴う溶藻現象 ここまでは主に実験室において $\beta$-cyclocitral によ るラン藻の青色化を伴う溶藻現象を議論してきた. 一方，野外ではラン藻が高密度で発生した湖面の一 部が青白色に変色した溶藻現象が生起することは早 くから知られ，溶藻活性を持つ原生動物や細菌等に ついての多くの報告がある. ${ }^{31-33)}$ また，溶藻現象と して認識されていないため溶藻現象とは記述されて いないが，多くのラン藻の水の華に関する総説や解 説等に出されている写真には白色や青色に変色した 部分がみられ，密度の高いアオコでは一般的な現象 である. ${ }^{34-36)} 2013$ 年 9 月，相模湖で青色化を伴う溶 藻が観察された。この年はこれまでで最も降水量が 少なかつたが，宮ヶ瀬湖からの導水により相模湖か らの放流量を減らしていたため，水位低下は $2 \mathrm{~m}$ 程度であり, 滞留時間は相模湖としては最も長く, 6-8 月の平均は約 16 日で, 発電放流を停止してい る時間が長かった。 9 月 6 日に取水口前からアオコ フェンス沿いに相模湖大橋付近まで青色化を伴った 溶藻現象が生起した。このとき，上流に向かった風 （海風）が吹き始め, 青白色のスカムがアオコフェ ンス沿いに湖心方向に流れていた. Station (St.) 8 の溶藻スカム, St. 7 のアオコフェンスより取水口 側の緑色のスカム, St. 6 の溶藻現象の地点から離 れた左岸よりの薄いラン藻を採取した。近寄れない ためサンプリングできなかったが，2001 年に溶藻 
<smiles>CC1=C(C=O)C(C)(C)CCC1</smiles>

$\beta$-cyclocitral<smiles>C1CCCCC1</smiles>

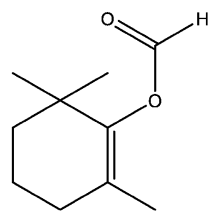

2,6,6-trimethylcyclohex-1-en-1-yl formate

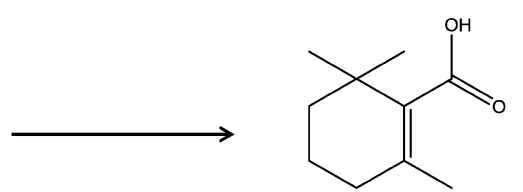

2,6,6-trimethylcyclohexene1 -carboxylic acid

Fig. 10. Reaction Scheme of $\beta$-Cyclocitral with Water

Reproduced with permission from Environ. Sci. Pollut. Res., 23(12), 11998-12006 (2016) . Copyright 2016 Springer.

現象が生起した地点 St. 5 がロープで囲われてお り，その地点においても青色化がみられた. ${ }^{37)}$

2013 年, 相模湖でのラン藻は, 7 月上一中旬及び 8 月下旬-9 月上旬は, Dolicospermum mucosum が 優占しており，9月 3 日 St. 5 では 84\%が D. mucosum，14\%がMicrocystis であったが，9月 6 日の St. 6 では D. mucosum がやや減少して $74 \%$ ， Microcystis 14\%であった。溶藻していた St. 8 では D. mucosum は 6\%に激減，Microcystis は 72\%に 増加して優占種となり，それまでは少なかった $D$. crassum は増加した. St. 7 もD. mucosum は 37\% に減少, Microcystis $63 \%$ になり, 優占種となつ た。一方，採取した湖水はろ過し，そのろ液を $\mathrm{Et}_{2} \mathrm{O}$ 抽出し, 通常の GC/MS により分析し, $\beta$-cyclocitric acid 等の $\beta$-cyclocitral の酸化生成物を分析 した。検出限界が $10 \mathrm{ng} / \mathrm{L}$ であり, $\beta$-cyclocitral は 検出限界以下であったが， $\beta$-cyclocitral の酸化生成 物である 3 化合物, $\beta$-cyclocitric acid, エノールエ ステル体の 2,6,6-trimethylcyclohex-1-en-1-yl formate, 2,2,6-trimethylcyclohexanone が高濃度で検出 され，pHの低下も確認された。 $\beta$-Cyclocitral の添 加実験では, 酸化生成物は $\beta$-cyclocitric acid が圧倒 的に多かったが, St. 8 においては, pH は 6.2 に低 下していたが 2,2,6-trimethylcyclohexanone の濃度 が $\beta$-cyclocitric acid より高いことが特徵的であった (Fig. 11)。なお，St. 6 では $\beta$-ionone だけが検出さ れ, St. 7 では細胞密度が高く, 通常は $\mathrm{pH}$ が 10 前
後あるはずであったが, pH は St. 6 より低く, $\beta$-cyclocitric acid も検出された. ${ }^{38)}$

\section{VOC による種々のラン藻類に対する感受性}

4-1. 各種ラン藻に対するVOC の MIC これ までに観察された溶藻現象の際，種組成の変遷がみ られ，特に 2008 年及び 2013 年で顕著であった。こ れは，ラン藻種により VOC に対する感受性に差が あるためであると考えられた。そこで，数種の NIES 保存株を購入し，各 VOC に対する MIC を測 定するとともに相模湖・津久井湖に出現するラン藻 類の感受性を比較した，MICの測定は，試験管法 とマイクロプレートリーダー法の両者を用いた， $\beta$ Cyclocitral, $\beta$-ionone, $\beta$-cyclocititric acid は $20 \mathrm{mM}$, 2,2,6-trimethylcyclohexanone は $40 \mathrm{mM}$ から順次 $1 / 2$ 濃度になるように 6 段階の MA 培地に各揮発性 化合物を添加した希釈列を $10 \mathrm{~mL}$ ずつ， $\beta$-cyclocititric acid は試薬量が少ないことから $1 \mathrm{~mL}$ ず つ用意し，等量のラン藻懸濁液を加えて培養した。

Microcystis NIES-298 に $\beta$-cyclocitral を添加した実 験の経過においては，10 mM の添加では瞬時に青 色化，翌日には退色し，5 mM の添加では翌日に青 色化，3 日目には退色などが観察された。通常は 5 日後, 野生株では 7 日後に擋挥後 $10 \mathrm{~mL}$ 中 $5 \mathrm{~mL}$ を, $\beta$-cyclocititric acid は全量を GF/A でろ過して chlorophyll $a$ を $\mathrm{MeOH}$ で抽出して濃度を測定し た。このような実験を各 3 回繰り返し，平均值を求 めた. ${ }^{39)}$ その結果, $\beta$-ionone, $\beta$-cyclocitral, $\beta$-cy- 


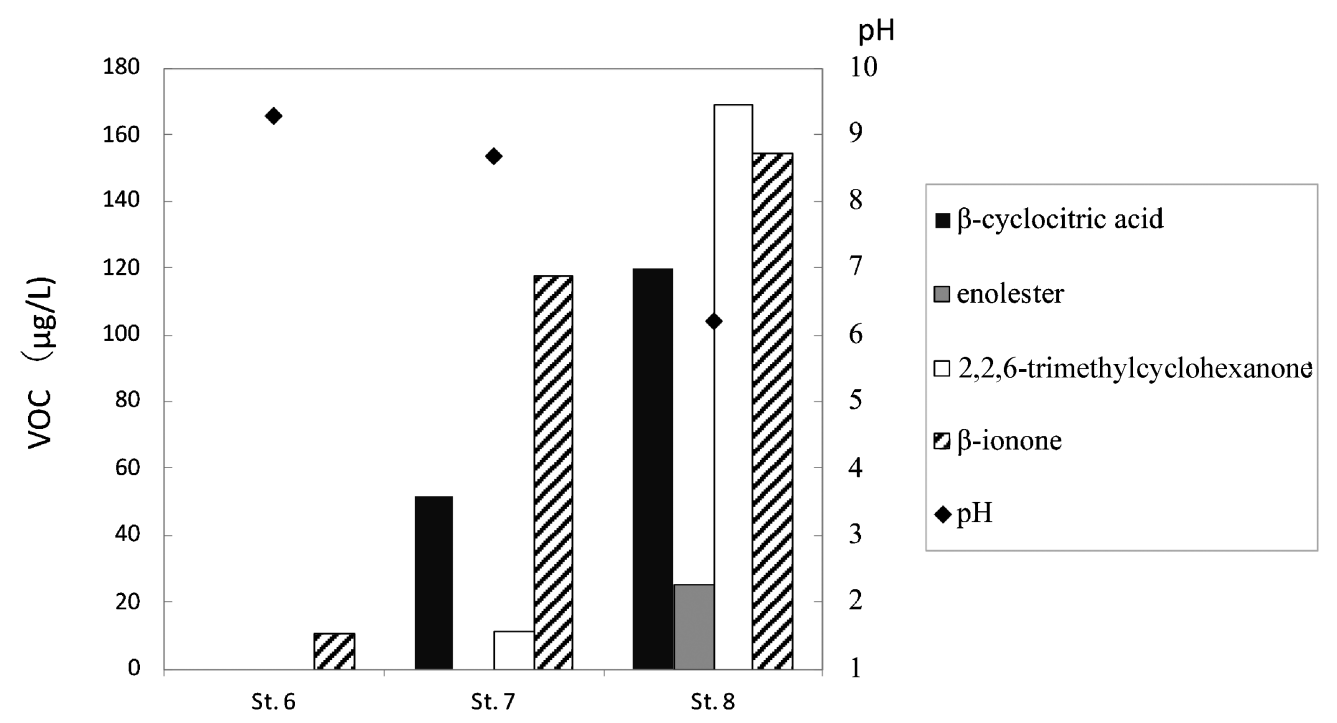

Fig. 11. Amounts $(\mu \mathrm{g} / \mathrm{L})$ of $\beta$-Cyclocitral and Related Compounds and $\mathrm{pH}$ Values in Collected Samples from Sts. 6, 7 and 8 at Lake Sagami on September 6, 2013

Reproduced with permission from J. Res. Inst. Meijo Univ., 15, 11-16 (2016). Copyright 2016 Meijo University.

clocitric acid, 2,2,6-trimethylcyclohexanone の順に 溶藻活性が強く, $\beta$-cyclocitral に対する感受性は, D. mendotae $>$ Aphanizomenon $>D$. affine $>D$. mucosum, D. ucrainicum $>$ D. crassum $>$ Microcystis の順に高く, 溶藻現象の際の種組成の変遷と一 致した。また，Microcystis は，自然界では，厚い 粘質物質に包まれ，細胞が密集していることから NIES 株を用いた実験室での感受性の違い以上に他 のラン藻より感受性が低い. 40)これは, 粘質物質に 保護され，塊になっていることにより，内部の細胞 に揮発性化合物が接触し難いことによると考えられ る。また, VOC の溶藻活性は, $\beta$-ionone $>\beta$-cyclocitral $>\beta$-cyclocitric acid $>2,2,6$-trimethylcyclohexanone の順に強かつたが， $\beta$-cyclocitral の酸化生 成物である $\beta$-cyclocitric acid と 2,2,6-trimethylcyclohexanone にも $\beta$-cyclocitral より弱いものの, 同 様に溶藻活性が認められた。しかし， $\beta$-cyclocitral 酸化後の酸化生成物濃度では閾值に達しないが，一 定時間後, 添加濃度に応じて chlorophyll $a$ 濃度が 低下することから最初に接触する $\beta$-cyclocitral 濃度 が重要である。また， $\beta$-ionone は $\beta$-cyclocitral より 溶藻活性が高いが, Microcystis 以外のラン藻も産 生することから $\beta$-cyclocitral より検出されることが 多く, 計算上の作用濃度を上回っているにもかかわ らず， $\beta$-ionone によると考えられる事例が 1 例し かないことから, 疎水性があまりに強いため, $\beta$ - cyclocitral と比較すると影響は少ないと考えられる.

4-2. $\log D$ を用いる作用濃度 MIC 測定で 得られた VOC 濃度は, 自然界から得た溶藻サンプ ルでの VOC 濃度よりけた違いに高い。 $\beta$-Cyclocitral を始めとする VOC は疎水性であり, 添加 した化合物のごく一部が水に溶解して溶藻活性を示 すと考えられる。. Table 1 に $\beta$-cyclocitral 及び関連 化合物の分配係数 $(\log D)$ を示した. Table 1 に 示した MIC 濃度（mM）を $\log D$ を自然数化した 数（ $\beta$-cyclocitral であれば 1820）で割った濃度 $(\mu \mathrm{M} / \mathrm{L})$ が， MIC の濃度の VOC を添加したとき に水に溶解し，ラン藻に作用すると考察した。 これ は，溶藻現象を引き起こす閾值に近い值とも言え る. 例えば，最も感受性の高い A. flos-aquae の $\beta$ cyclocitral による MIC は $0.6 \mathrm{mM}$ で，その $1 / 1820$ である $0.3 \mu \mathrm{M}(50 \mu \mathrm{g} / \mathrm{L})$ が $0.6 \mathrm{mM}$ を添加したと きに作用し, chlorophyll $a$ が $50 \%$ となる濃度であ る。これは, 2008 年に津久井湖での溶藻現象の際 に得られた 8 月 5 日の $50 \mu \mathrm{g} / \mathrm{L}, 12$ 日 $100 \mu \mathrm{g} / \mathrm{L}$ と 同等である。しかしながら，この濃度では Microcystis は溶藻しない。 また， $\beta$-cyclocitral は，すみ やかに酸化されて $\beta$-cyclocitric acid 及び 2,2,6trimethylcyclohexanone になる。半減期は 1 時間程 度で，これらの酸化生成物は溶藻活性が低く, 20 倍以上の高濃度でないと作用濃度にならないが, 酸 化生成物ではなく，最初に添加した $\beta$-cyclocitral 濃 
度に応じて, 数日後に溶藻していた. したがって, 最初に接触する VOC 濃度が重要である。このよう に，各 VOC はその溶藻活性が異なり，それに基づ いてラン藻の種により感受性に差が生じ, 自然界で 生起する溶藻現象における種の変遷が説明可能と なった．結果的に，これは自然界での種の変遷と一 致し, 感受性の高い種は, Microcystis が増殖する と減少する傾向となる。 さらに, 溶藻現象が起こら ない濃度でも沈降し易くなるなどの影響があり，種 の変遷に $\beta$-cycloctral が関与している可能性が強く 示唆された. ${ }^{39)}$

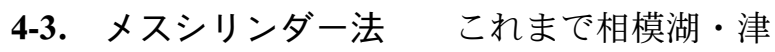
久井湖で観察された溶藻現象は，いずれも堰堤に近 く, ラン藻が高密度に集積したところで生起してい たことから，密度ストレスが溶藻現象，そしてそれ に引き続く種の変遷の引き金の 1 つとして重要な役 割を果たしていると推察された。このことを検証す るために以下に示す一連の実験を行った。すなわ ち, 津久井湖から採取したラン藻をメスシリンダー に入れて静置し，ラン藻が持つガス胞による浮上能 力を利用して稠密化し, 経過を観察した（メスシリ ンダー法).41) 7 月 22 日，ゴミ除けフェンス脇に集 積していたラン藻を採取し, $500 \mathrm{~mL}$ のメスシリン ダーに注いだ。採取したラン藻類では，D. affine が優占種で，ついでD. mendotae, Microcystis であ り, A. flos-aquae は非常に少なく, $10^{4}$ 細胞 $/ \mathrm{mL}$ 以 下であった。 ラン藻の合計細胞密度は, $8.3 \times 10^{6}$ 細胞 $/ \mathrm{mL}$ であったが, 5 時間後にはラン藻は上層 $60 \mathrm{~mL}$ に移動し, 細胞密度は 10 倍になった。翌 日，上層のラン藻は約 $40 \mathrm{~mL}$ になり，約 $20 \mathrm{~mL}$ は 底層に沈降した. D. mendotae は底層に多く, 上層 では減少していたが, Microcystis は上層のほうが やや多かつた。このときの上層の細胞は健全に見え たが, 底層に沈降したラン藻は群体が小さく, 単細 胞になったものもみられ，細胞はガス胞が少なく， 弱つているようであった。 2 日後は，変化していな いように見え，サンプリングしなかったが，3 日後 には上層のラン藻は非常に少なくなり, 底層のラン

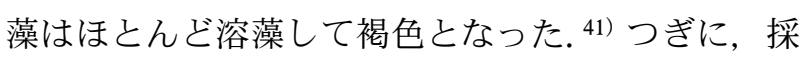
取試料の $\mathrm{pH}$ 值, $\beta$-cyclocitral とその関連化合物の 分析結果 $(\mu \mathrm{g} / \mathrm{L})$, Microcystis の細胞密度 (細胞/ $\mathrm{mL})$, ラン藻全体の細胞密度（細胞 $/ \mathrm{mL}$ ）を測定 した. 22 日の開始時の試料（A）は，すぐには $\mathrm{Et}_{2} \mathrm{O}$
抽出できなかつたため, 試験管に分取して冷蔵庫に 保管， 3 時間後に抽出しようとしたときは，試験管 の中で上下の層に分かれており, 津久井湖で多項目 測定器を用いた現場での測定では $\mathrm{pH}$ は 9.9 であっ たが，この試験管では 7.8 に低下していた。 $\beta$-Cyclocitral 濃度は, $10 \mu \mathrm{g} / \mathrm{L}$ 以下であったが， $\beta$-cyclocitric acid, 2,2,6-trimethylcyclohexanone, $\beta$-ionone が検出された． 5 時間後の試料（B）からは $\beta$ cyclocitral も検出された。翌日の試料は, 表層 (C) 及び底層（D）のろ液が青色を呈し， $\beta$-cyclocitric acid が検出され， $\beta$-cyclocitral は全層で検出され た。（B）から（D）の表層及び（C）から（D）の 底層では $\mathrm{pH}$ は約 6 に低下し, $\beta$-cyclocitric acid が 検出された。 2,2,6-Trimethylcyclohexanone 及び $\beta$ ionone はすべての試料から検出された. ${ }^{41)}$

4-4. ラン藻の種の変遷 メスシリンダー法を 用いて湖沼から得たラン藻を稠密化する実験の結 果, 細胞密度を成功裏に増加させ, 最大細胞密度は $8.3 \times 10^{7}$ 細胞 $/ \mathrm{mL}$ に達した. ラン藻を含む湖水の $\mathrm{pH}$ は，実験前は 10 前後であったが，これまで相 模湖・津久井湖でみられた溶藻試料と同様 6 前後に 低下し，青色化が観察され， $\beta$-cylocitral とともに $\beta$-cyclocitric acid を検出した. ${ }^{41)}$ メスシリンダー実 験により, ラン藻類が稠密化され, 結果的に Microcystis 細胞から $\beta$-cylocitral を放出させ, Microcystis 細胞自身及び Dolichospermum などの 他のラン藻を溶解させた。 さらに, $\beta$-cylocitral は 対応する $\beta$-cyclocitric acid 及び 2,2,6-trimethylcyclohexanone 乞と急速に酸化され，pH は急速に低 下し，その酸ストレスによって chlorophyll $a$ 及び $\beta$-carotene は分解された。これらの連続する事象の 結果として, phycocyanin が残存することにより青 色化が達成されたことになる。 上層に浮上したラン 藻は, およそ $2: 1$ の割合で表層と底層に分かれ, 脆弱又は死んだ細胞は, 2008 年津久井湖並びに 2013 年相模湖での溶藻した試料と同様，ガス胞が ほとんどなく, 沈降した。 2013 年相模湖の溶藻し た試料では D. mucosum のヘテロサイトが多数残 存していたが, この実験ではD. mendotae とD. affine のへテロサイトは非常に小さくて少ないた め, 観察できなかったが, 2008 年の溶藻した試料 と同様に多くのアキネートが沈殿物中にみられた. 一方, Microcystis 細胞は表層に残存していた. 
Crayton は, ラン藻は異常な高密度では長期間維持 することはできず， 1-2 週間で急激に死滅し，条件 がよければ別種のラン藻の水の華が急速に置き換わ

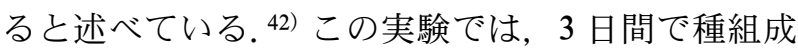
が変わつた．溶藻したラン藻の細胞密度を考慮する と, 相模湖では 2013 年に溶解前の数は $4.1 \times 10^{7}$ 細 胞 $/ \mathrm{mL}$ と推定され，この実験と同レベルであっ た。したがって，ラン藻の密度ストレスにより Microcystis が $\beta$-cylocitral を産生し，それが素早く 酸化され, 結果的に生じる酸ストレスにより青色化 を伴う溶藻現象が生起したことになる.

これまで相模湖・津久井湖で観察された溶藻現象 は，いずれも堰堤に近く，ラン藻が高密度に集積し たところで生起していたことから，密度ストレスが 溶藻現象の引き金の 1 つとして重要な役割を果たし ていると推察された。ここでは，メスシリンダー法 を用いて青色化を再現する一連の実験を行った． 結 論として，溶解プロセス全体を視認化することが可 能であるという利点を有するメスシリンダー法を用 いてラン藻を濃縮することによって, 自然条件下と 同じ溶解現象を再現することができた。すなわち, 濃縮過程中, 密度ストレスによって Microcystis か ら $\beta$-cyclocitral が放出され, 短時間でカルボン 酸に酸化され，水の $\mathrm{pH}$ は約 6 まで低下した.

Dolichospermum 及び Microcystis を含むラン藻 は, ほとんどの細胞が溶藻し, 溶出した chlorophyll $a$ 及び $\beta$-carotene は酸ストレスによって分 解され, phycocyaninのみが残って青色を呈した。 最終的に, 少数の Microcystis が残り, 優占した. この引き金となる細胞密度は $10^{7}$ 細胞 $/ \mathrm{mL}$ 以上 で, これは相模湖で溶藻現象が生起したときの推定 值と一致していた。 また, これらの結果は種の変遷 は $\beta$-cyclocitral により引き起こされていることも示 している.

\section{5. $\beta$-Cyclocitral の産生挙動とその産生条件}

5-1. 各種環境条件による $\beta$-cyclocitral 産生因子 溶藻活性を有するVOCs のうち $\beta$-cyclocitral 及び $\beta$-ionone は, ラン藻が保有する光合成色素の 1 つ である $\beta$-carotene が carotenoid cleavage dioxygenase (CCD) により酸化開裂を受けることで生成 される. ${ }^{43)}$ 一体, ラン藻はどのように環境中の因子 を感知し, $\mathrm{CCD}$ を活性化させ, $\beta$-cyclocitral を産 生，放出しているのであろうか。この因子につい
て, 古くは細胞の破壊が産生条件の 1 つであると予 想されており, ${ }^{11)}$ その後様々な研究から他の微生物 による攻撃，飢餓，揮発性化合物による細胞破壊や 細胞数増加によるストレス等が因子として挙げられ ている。しかしながら，どのような因子が CCD の 活性化及び $\beta$-cyclocitral の産生充進に寄与するかの 検証は行われていない。ここでは，過去の継代培養 や湖沼生態系での知見に基づき，ストレス因子とし て照度・栄養・細胞密度に関する 3 種の培養条件を 設定した。物理的因子である照度条件について, 通 常の $1500 \mathrm{~lx}\left(28 \mu \mathrm{Em}^{-2} \mathrm{~s}^{-1}\right)$ に対して $2500 \mathrm{~lx}$ (56 $\left.\mu \mathrm{Em}^{-2} \mathrm{~s}^{-1}\right)$ の高照度条件と $300 \mathrm{~lx}\left(3 \mu \mathrm{Em}^{-2} \mathrm{~s}^{-1}\right)$ の低照度条件を設定した。 $\beta$-Cyclocitral は植物にお いて強光阻害に適応するための化合物と位置付けら れており, 43) ラン藻においても同様の機能を有する 可能性がある。 また，湖沼における $\beta$-cyclocitral の 検出時期は晚夏に集中しており，日照量の減少が $\beta$-cyclocitral の産生に寄与するか検証を行った。つ ぎに, 化学的因子である栄養条件では, 培養に用い るMA 培地からラン藻の成長に必須とされる窒素 とリンを減じた。 窒素制限条件は通常と比較して窒 素を半減, リン制限条件ではリン量を $1 / 4$ に設定し ている。これは予備試験において M. aeruginosa NIES-843 が培地のリンを半減させても細胞成長に ほとんど影響を及ぼさなかった点, 及び MA 培地 の組成が比較的リンが過剩であることに基づいてい る. ラン藻が密集した際に栄養飢餓状態となること が予想されるため, これらに応答して $\beta$-cyclocitral が産生されるか検証を行つた. 最後に, 生物学的因 子である高密度条件について, 通常 $10^{6}$ 細胞 $/ \mathrm{mL}$ から培養を開始するところ, 10 倍である $10^{7}$ 細胞/ $\mathrm{mL}$ と 100 倍である $10^{8}$ 細胞 $/ \mathrm{mL}$ を初期密度として 設定した。なお，初期密度を $10^{8}$ 細胞 $/ \mathrm{mL}$ とする 高密度条件を技術的に設定できず，結果的に 30 倍 に相当する $3 \times 10^{7}$ 細胞 $/ \mathrm{mL}$ で実験を行った（Table 2).

ラン藻の細胞成長を評価するため, 細胞数・濁 度・pH・濾物乾燥重量・光合成色素の測定及び培 養液の観察を行つた. 細胞数・濁度・乾燥重量は直 接的にラン藻の細胞量を計測するものであり，基本 的には Burker-Turk 血球計算盤を用いた細胞の直 接計数を主とし，ほかはその補強という位置づけと した. $\mathrm{pH}$ はラン藻の成長指標を表し, 通常光合成 
Table 2. $\beta$-Cyclocitral Producing Factors under Different Environmental Conditions

\begin{tabular}{l|l|l|l}
\hline \hline & \multicolumn{2}{|c|}{ Culture conditions } & \multicolumn{1}{c}{ Detailed conditions } \\
\hline Physical & Illuminance & Higher intensity & $\begin{array}{l}28 \mu \mathrm{Em}^{-2} \mathrm{~S}^{-1} \\
\rightarrow 56 \mu \mathrm{Em}^{-2} \mathrm{~S}^{-1} \\
28 \mu \mathrm{Em}^{-2} \mathrm{~S}^{-1} \\
\rightarrow 2.8 \mu \mathrm{Em}^{-2} \mathrm{~S}^{-1}\end{array}$ \\
\hline Chemical & Nutrition & $\begin{array}{l}\text { Nitrogen } \\
\text { restriction } \\
\text { Phosphorus } \\
\text { restriction }\end{array}$ & $\begin{array}{l}200 \mathrm{mg} \mathrm{N}_{2} \\
\rightarrow 100 \mathrm{mg} \mathrm{N} \\
100 \mathrm{mg} \mathrm{P} \rightarrow 25 \mathrm{mg} \mathrm{P}\end{array}$ \\
\hline Biological & Cell density & Higher density & $\begin{array}{l}1.0 \times 10^{6} \\
\rightarrow 1.0 \times 10^{7} \text { cells } / \mathrm{mL} \\
1.0 \times 10^{6} \\
\rightarrow 3.0 \times 10^{7} \text { cells } / \mathrm{mL}\end{array}$ \\
\hline
\end{tabular}

が活発に行われると水中の二酸化炭素が消費され塩 基性に傾く. ${ }^{28,37)}$ ラン藻が有する光合成色素である chlorophyll $a$, phycocyanin, $\beta$-carotene は細胞成長 の指標となり, 上述した 3 種の色素の定量を行っ た。培養液の観察は写真撮影により色調を比較し た．通常，新しい培地に植え継いだラン藻はしばら くすると対数的に増殖し, 淡い緑から濃緑色に変化 する．その後に増殖と死滅が平衡となる定常期を経 て，やがて死滅が優勢となり細胞数は減少していく. $\beta$-Cyclocitral を始めとするVOCs の分析項目とし て，ラン藻培養液中の細胞内外の VOCs を対象と するVOCs（total）と，濾液のみを対象とする VOCs（filtrate）の分析を行った．分析法は藤瀬ら の開発した一斉分析法に基づいて, 固相マイクロ抽 出（solid-phase microextraction; SPME） GC/MS と溶媒抽出-GC/MS を併用した。 ${ }^{44)}$ 前者はVOC (total) に存在する $\beta$-cyclocitral の分析に，後者は VOC (filtrate) 中の $\beta$-cyclocitric acid の分析に適用 した.

\section{5-2. 各種培養条件下の $\beta$-cyclocitral の産生挙動}

M. aeruginosa NIES-843 に対する各種培養条件 を Table 2 に示す，細胞成長に関しては，高照度で は大きく抑制，低照度では光合成能が低下するため か成長が遅延した。窒素制限・リン制限では定常期 を迎えることなく早期に細胞が減少し，栄養源の不 足が増殖抑制因子となったことが示された。また，

初期密度 $10^{6}$ 細胞 $/ \mathrm{mL}$ に対して 10 倍程度が最大到 達密度となるところ，高密度条件ではそれぞれ 1.5 倍・1.1 倍程度が最大到達密度であり，同じく細胞 成長の抑制因子であることが示された。また，30
倍の高密度条件では， 6 週目に急激に細胞数が減少 した。光合成色素の変化について, chlorophyll $a$ はおよそ共通して 1 週に最大值をとり，その後減少 傾向となった。播種直後の対数増殖に合わせて chlorophyll $a$ が合成されていることが予想され る。一方, $\beta$-carotene は各条件の外観が黄色に変化 するタイミングで最大值となっており，いずれの条 件においても 3-4 週まで増加し続ける傾向にあった.

Phycocyanin は chlorophyll $a$ 同様 1-2 週に最大值 をとつた後, chlorophyll $a$ よりも早く減少してい た。また, phycocyanin の定量值は chlorophyll $a$ や $\beta$-carotene の 5 倍程度となった。 $\mathrm{pH}$ はいずれも chlorophyll $a$ と同様の推移をとり, 1-2 週で上昇し その後減少していく結果が示された.

$\beta$-Cyclocitral と $\beta$-ionone は，すべての条件の VOCs（total）から検出された。さらに，VOCs (filtrate) からは $\beta$-cyclocitric acid が検出された. また， $\beta$-ionone は $\beta$-cyclocitral とともに検出されて おり，その検出量は $\beta$-cyclocitral の 2 割程度であ る。それぞれの産生条件について，対照群では 1 週 から 8 週にかけて $\beta$-cyclocitral が検出され, $\beta$-cyclocitric acid は 1 週より検出された後時間がたつご とに増加した。これに対し，高照度条件では検出さ れた $\beta$-cyclocitral は少なかつたものの, $\beta$-cyclocitric acid が多量に検出された。低照度条件では,

2 週より $\beta$-cyclocitral の検出量が増加し， 14 週まで 維持されたが， $\beta$-cyclocitric acidの検出量はそれほ ど多くなかった。窒素制限では 1 週から 3 週, リン 制限では 1 週から 4 週まで $\beta$-cyclocitral が検出され,

$\beta$-cyclocitric acid の検出量は同程度であった。密度 条件で用いた対照群は 1 週から 5 週にかけて $\beta$-cyclocitral が検出され， $\beta$-cyclocitric acid は同様に増 加していつた。高密度条件ではいずれも 0 週から $\beta$-cyclocitral が検出され，10 倍では 3 週以降対照群 と同じ挙動をとり， 30 倍では 5 週まで大量に $\beta$-cyclocitral が検出された。また， 30 倍のみ $\beta$-cyclocitric acid が減少し，6 週から定量限界を超えな かった (Fig. 12).

5-3. $\quad \beta$-Cyclocitral の産生に関する考察 $\quad \beta$-Cyclocitral の産生は, $\beta$-carotene が CCD により酸化 開裂を受け，生成されるという仮説に基づき, $\mathrm{CCD}$ 六進因子を明らかにすることを目的とした。 照度・栄養制限・細胞密度の各条件を設定して培 
(a)

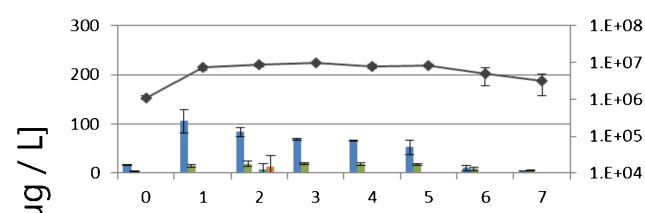

(c)

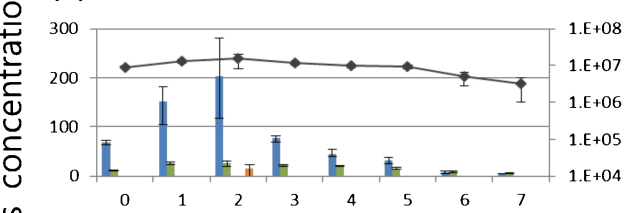

仓ั $(e)$

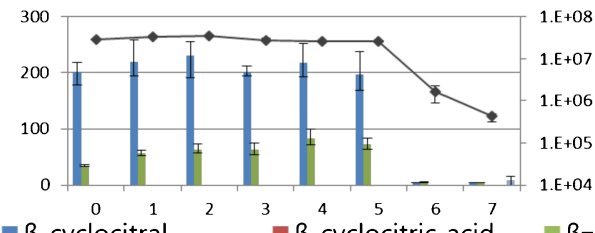

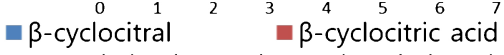

- 3-methyl-1-butanol $\approx$ 2-phenylethanol (b)

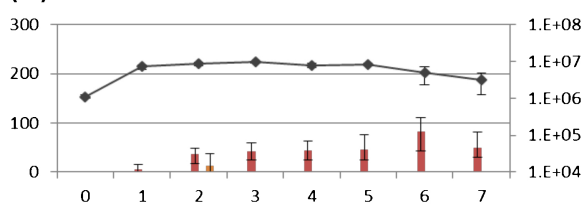

(d)

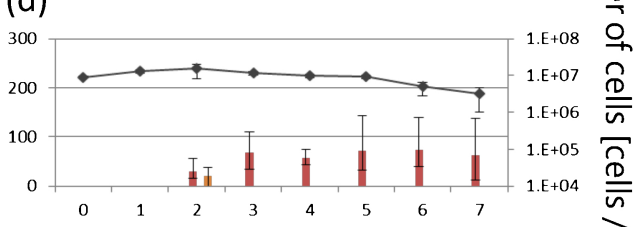

(f)

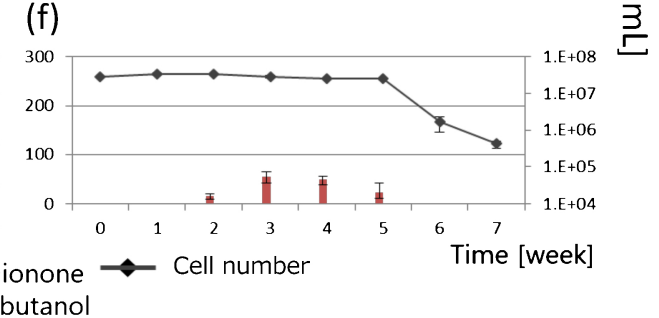

Fig. 12. VOC Quantification Results and Changes in Cell Number of Microcystis aeruginosa NIES-843 under Higher Density Conditions

(a) Control VOC (Total); (b) Control VOC (Filtrate), (c) 10 Fold (Total); (d) 10 Fold (Filtrate); (e) 30 Fold (Total); (f) 30 Fold (Filtrate). (Color figure can be accessed in the online version.)

養・分析を行い, 細胞数が $10^{7}$ 細胞 $/ \mathrm{mL}$ を超えて いる間, $\beta$-cyclocitral が産生されるという結果を得 た。より詳細に $\beta$-cyclocitral の産生挙動を検討する ために，M. aeruginosa NIES-843 を用いて，初期 密度を $10^{6}$ 細胞/ $\mathrm{mL}$ に設定して培養を開始した。 分析項目は細胞成長の評価としては細胞数のみとし, VOCs 分析法は VOCs（total）として溶媒抽出-GC/ MS 法と加熱-溶媒抽出-GC/MS 法の 2 種を行った (Fig. 13)。青線は細胞数，赤は $\beta$-cyclocitral，緑は $\beta$-ionone，紫は $\beta$-cyclocitric acidのそれぞれの分析 值を示している．細胞成長は上述の結果と比較する と遅く, 18 日目にようやく $10^{7}$ 細胞 $/ \mathrm{mL}$ に到達し た。 その後, 24 日から 72 日目まで定常期を迎えた 後, 死滅期となった. $10^{7}$ 細胞 $/ \mathrm{mL}$ を超えていた期 間は 17 日から92 日目までである。 $\beta$-Cyclocitral は，やはり通常の溶媒抽出法では検出されなかった が [Fig. 13(b)], 加熱-溶媒抽出法では確実に検出 されている [Fig. 13(a)]。この結果は $\beta$-cyclocitral はそのままの形で培養液中に存在しておらず，加熱 のような刺激を受けて初めて検出されたことを示し ている. $\beta$-Cyclocitral の検出は $10^{7}$ 細胞 $/ \mathrm{mL}$ に到達 した 17 日目では検出されず，24 日以降に検出さ れ，またこの日を境に定常期へ移行した， $\beta$-Ionone
も同時期から増加傾向にあり，40 日目まで維持さ れる. また, $\beta$-cyclocitric acid はどちらの分析条件 でも検出され，75 日から95 日まで検出された。

これらの結果から, $\beta$-cyclocitral の産生には $10^{7}$ 細胞 $/ \mathrm{mL}$ 以外に定常期への到達が重要であり, 加 熱条件における検出は高密度かつ定常期以降に中間 体が生成・蓄積されることを示唆している。 また, 定常期は増殖と死滅が同等で見掛け上細胞数が維持 される期間であり，定常期への移行とともに $\beta$-cyclocitral 前駆体の蓄積が開始されることは, 高密度 環境に対する応答の 1 つであると推察される. また,

M. aeruginosa NIES-843 の死滅期付近で $\beta$-cyclocitric acid の検出量が増加し, 加熱を含まない通 常の溶媒抽出においても増加している [Fig. 13(b)].

$\beta$-Cyclocitric acid は過去の $\beta$-cyclocitral 産生を示 し, 該当する期間において, 自然発生的に $\beta$-cyclocitral が放出される要因が存在していることが予 想される. 細胞数と $\beta$-cyclocitral 及び $\beta$-cyclocitric acid の変化を比較すると， 72 日以降， $\beta$-cyclocitric acid 増加後に細胞数と $\beta$-cyclocitral 量が減少し, さ らに $\beta$-cyclocitric acid の検出量が最も高い 84 日を 境にさらに $\beta$-cyclocitral 量が減少し, 細胞が死滅し ている. 以前に, $\beta$-cyclocitral と $\beta$-ionone の検出量 


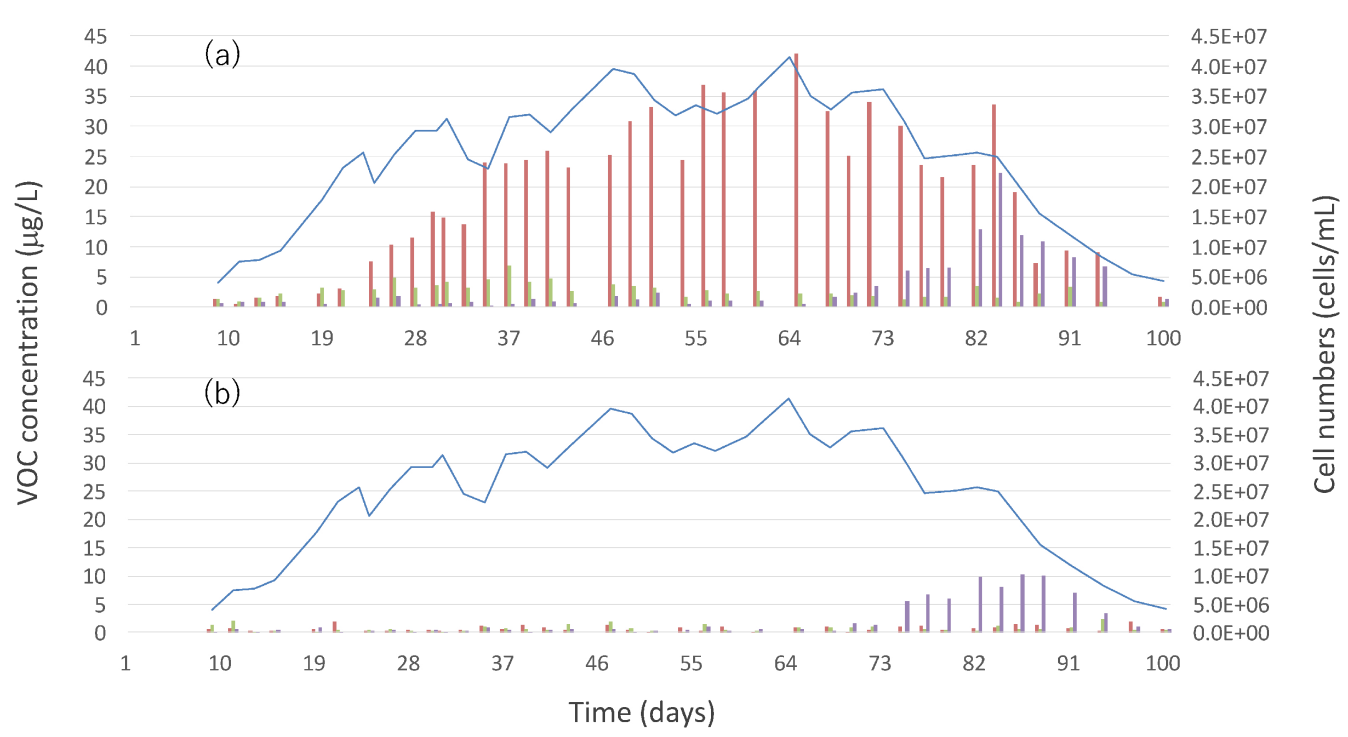

Fig. 13. VOC Quantification Results and Changes in Cell Number of Microcystis aeruginosa NIES-843

(a) GC/MS-solvent extraction with heating; (b) GC/MS-solvent extraction. The colored lines indicate the followings: blue, cell number; red, amount of $\beta$-cyclocitral; green, amount of $\beta$-ionone; purple, amount of $\beta$-cyclocitric acid. (Color figure can be accessed in the online version.)

と死滅との関連性を指摘したが，本実験からも死滅 の進行と自然的な $\beta$-cyclocitral の放出は密接な関係 があることが示唆された，以上の結果から，溶藻活 性化合物である $\beta$-cyclocitral は，単純な細胞密度に 依存しているのではなく, 細胞增殖段階と密接な関 連があることが示唆される，すなわち，増殖が優勢 となる対数増殖期では $\beta$-cyclocitral は産生されず, 増殖と死滅が均衡状態となる定常期において $\beta$-cyclocitral の前駆体が細胞内に蓄積され， $\beta$-cyclocitral が産生・放出されることで死滅期に移行す ることが予想される。

\section{5-4. $\quad \beta$-Cyclocitral は Microcystis 属ラン藻により} 特異的に産生される $\quad \beta$-Cyclocitral が Microcystis 属に特異的であるかどうかを明らかにするため に, 種々のラン藻の VOC 産生挙動を調査した.こ の目的のために, クロオコックス目から 2 種 ( $M$. aeruginosa NIES-843, Synechocystis sp. PCC6803), ユレモ目から 2 種 (Pseudanabaena sp. NIES-611, Planktothrix agardhii NIES-989), ネンジュモ目か ら 1 種 (Dolichospermum lemmermannii NIES-808) を使用した。 Figure 14 に各種ラン藻の VOCs 定量 結果を示す。 $\beta$-Cyclocitral は M. aeruginosa NIES843 のみ, $\beta$-ionone, 3-methyl-1-butanol や 1-butanol は, 定量值に差異はあるものの全種のラン藻から検 出された. $\beta$-Cyclocitral は M. aeruginosa NIES-843 のすべての週から検出され, 3 週目に最大となった.
1 週以降，細胞数が維持されているにもかかわらず $\beta$-cyclocitral は増加していき，その後細胞数の減少 とともに減少した。. M. aeruginosa NIES-843 以外 の 4 種は, VOCs のうち $\beta$-ionone が最も多く検出 された。 その産生挙動は細胞数に比例しており, Synechocystis sp. PCC6803 以外の 4 種では, 細胞 量が最大を示す週の前後に最大值となっている.

Synechocystis sp. PCC6803 は 3 週以降の細胞数が 増加傾向であり, $\beta$-ionone も増加傾向であること から, さらに高密度に到達することが予想される. 種類によって細胞数は大きく違うが， $\beta$-ionone の 検出量はそれほど変化していない．２種のアルコー ル類のうち $10 \mu \mathrm{g} / \mathrm{L}$ が 2 週以上にわたり検出された ラン藻を挙げると, 3-methyl-1-butanol が $D$. lemmermannii NIES-808 と P. agardhii NIES-989 か ら, 1-butanol が M. aeruginosa NIES-843 と Pseudanabaena sp. NIES-611 から検出された. 前者は比 較的実験の前半に, 後者は後半に検出される傾向を 示した.

Microcystis 属である NIES-843 から $\beta$-cyclocitral が検出され, 本化合物は Microcystis 属ラン藻に特 異的であるという仮説と一致した．この結果を確認 するために, 当研究室で既に植え継ぎが行われてい る 4 属 14 種のラン藻を用いて分析を行った.これ らをMicrocystis 属とそれ以外に分け, 検出される VOCs を比較した. Microcystis 属ラン藻 7 種の $\beta$ - 


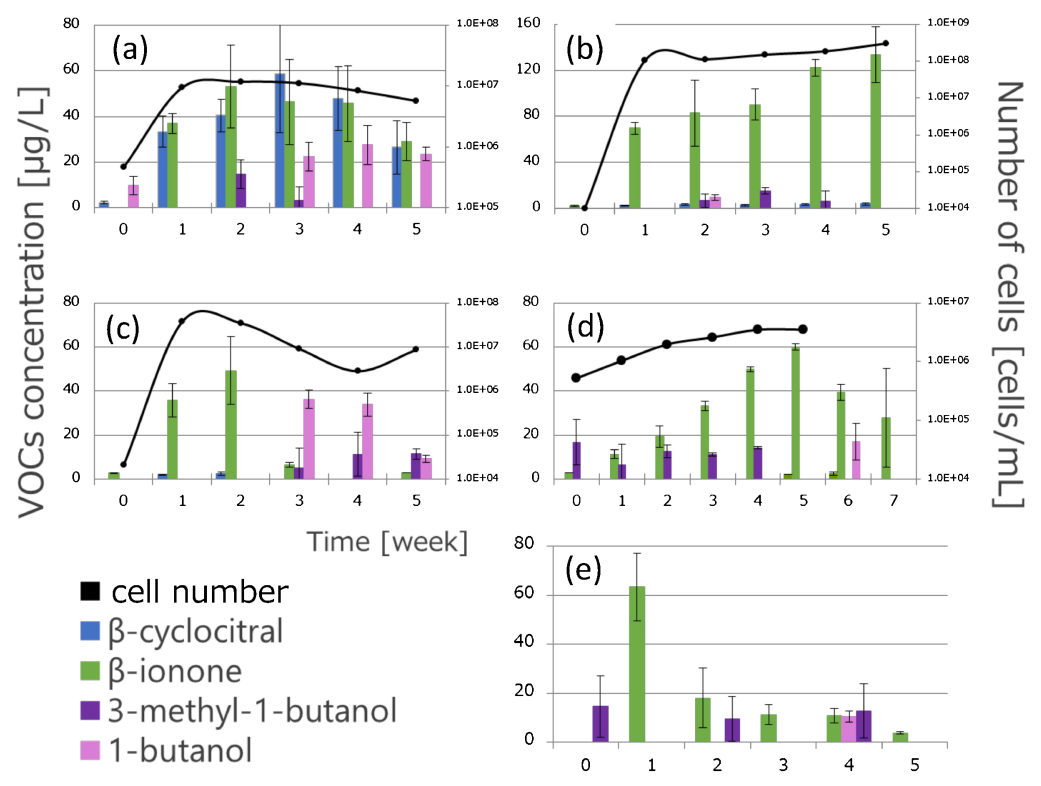

Fig. 14. Quantitative Results of 5 Different Species of Cyanobacteria

(a) Microcystis aeruginosa NIES-843; (b) Synechocystis sp. PCC6803; (c) Pseudanabaena sp. NIES-611; (d) Anabaena lemmermannii NIES-808; (e) Planktothrix agardhii NIES-989. (Color figure can be accessed in the online version.)

cyclocitral の検出量に着目すると，22 日目の NIES843 では, 酸添加後の検出量は $40 \mu \mathrm{g} / \mathrm{L}$ となってお り，多量の $\beta$-cyclocitral が検出された。 NIES-102, NIES-103 は，それぞれ培養後 106 日目，48 日目の ラン藻が最も多くの $\beta$-cyclocitral を検出した. NIES-298 では非添加時と比較して 1.5-2 倍ほどで あるが検出量が増加した。 また，100日を超えたラ ン藻では細胞数はそれ以前のものよりわずかである が細胞数は減少しており，死滅期に移行していると 考えられる。しかしながら，多くの Microcystis 属 ラン藻では 100 日目以降でも細胞数は $10^{7}$ 細胞 $/ \mathrm{mL}$ 以上を維持しており， $\beta$-cyclocitral は検出され続け た。つまり，個体差はあるが，定常期は比較的長 く, いずれにおいても酸添加条件で $\beta$-cyclocitral の 検出量は増加した。 $\beta$-Cyclocitric acid は, 酸添加条 件に関係なく，50-100 日目を超えたラン藻類か ら，検出され始めている傾向にある．それらの多く は非添加群の方が酸添加群よりもわずかながら值が 上回る結果が得られた。 $\beta$-Ionone は，わずかなが ら酸添加条件において検出量の増加が確認できた.

Microcystis 属ラン藻以外の 3 属 7 種では $\beta$-cyclocitral, $\beta$-cyclocitric acid は $1.0 \mu \mathrm{g} / \mathrm{L}$ 未満しか検 出されず，酸添加条件を加えても検出量に変化はみ られなかった。 以上， 7 種の Microcystis 属ラン藻 からは酸添加条件において $\beta$-cyclocitral が検出され,
Dolichospermum 属と Synechocystis 属, Pseudanabaena 属においては $\beta$-ionone は検出されたが, $\beta$-cyclocitral は検出できなかった，以上の結果から $\beta$-cyclocitral は Microcystis 属ラン藻に特異的であ ると結論付けられる。

\section{6. $\beta$-Cyclocitral はどのように産生されるか}

6-1. CCD による $\beta$-cyclocitral の産生 $\beta$-Cyclocitral は，植物界では $\beta$-carotene の二次代謝産物 であることが判明しており，強光阻害に対する応答 物質として位置づけられている. ${ }^{45)}$ ラン藻において は，これまでのところアオコを形成する代表的な種 である Microcystis 属ラン藻のみから検出されてお り，種特異的な化合物である. ${ }^{45)}$ 植物・ラン藻とも に $\beta$-cyclocitral や $\beta$-ionone は $\beta$-carotene の二重結 合が酸化的に開裂されることで産生され，その反応 を触媒するのがカロテノイド開裂酸化酵素 (CCD) である。CCD は 7 種に大別され，それぞれ基質や 反応位置が異なり特異的な機能を有することが報告 されている. ${ }^{43)}$ ラン藻においては，M. aeruginosa NIES-843 を始め様々な種の全ゲノムが解読されて いる. ${ }^{46,47)}$ Cui らは, ラン藻ごとにどのような系統 の CCD を保有するかを報告している. ${ }^{48)} \beta$-Cyclocitral を産生する M. aeruginosa NIES-843 は $\mathrm{CCD} 7$ と apo-carotenoid oxygenase (ACO) の 2 種 の酸化開裂酵素を保有しており，前者は $\beta$-carotene 
を $9^{\prime}, 10^{\prime}$ 位で酸化開裂させ, $\beta$-ionone と $\beta$-apo- $10^{\prime}$ carotenal を生成させる。，一方，後者は双方の末端 にシクロヘキセン環を持つ $\beta$-carotene を基質とす ることができず，例えば CCD7 の副生成物のよう な環を 1 つのみ有する $\beta$-apo-10'-carotenal を基質と して反応することができ， $15,15^{\prime}$ 位で酸化開裂させ て retinal を産生する. 当研究室の長谷川らは, $M$. aeruginosa NIES-298 から CCD 酵素と思われる 2 種の配列を選択し，MaCCD1 と MaCCD2 として 単離し, 後者は $\beta$-apo- $8^{\prime}$-carotenal を retinal に変換 することにより， MaCCD2 が ACO に相当する機 能を持つことを明らかにした（未発表データ）。 $\beta$ Cyclocitral に関して, Jüttner らは Microcystis 属か ら $\beta$-cyclocitral 及び crocetindial が検出されたと報 告している. ${ }^{11)}$ すなわち， $\beta$-carotene を基質として $7^{\prime}, 8^{\prime}$ - 位で切断して $\beta$-cyclocitral と $\beta$-apo- $8^{\prime}$-carotenal を産生し, さらに再度酸化開裂が起こり 2 分 子の $\beta$-cyclocitral と 1 分子の crocetindial が産生さ れるとしている。しかしながら， $\beta$-cyclocitral の生 合成に関与する CCD の報告はこれまでになされて おらず, $\beta$-cyclocitral の生合成については不明のま まである.

\section{6-2. ラン藻由来 VOC の分析法一加熱因子と酸} 添加 ラン藻由来 VOCs の分析には 2010 年に藤 瀬らが開発した一斉分析法を用いてきた. ${ }^{44)}$ 本法は, SPME-GC/MS 法と溶媒抽出-GC/MS 法を併用す るものであり, $\beta$-cyclocitral が SPME-GC/MS 法で,

$\beta$-cyclocitric acid が溶媒抽出-GC/MS 法でのみ定量 可能である。しかしながら，これらの分析法が $\beta$-cyclocitral や酸化生成物の分析に適しているか否 かに関する詳細な理由は明らかにされていない.

Zhang らは本分析法に従って同一の試料を SPMEGC/MS 及び溶媒抽出-GC/MS を用いて分析を行 い，それぞれの化合物が一方でしか分析されないこ とを再現している. ${ }^{49)}$ 藤瀬ら及び Zhang らはとも に結果の違いは分析方法によるものと考察している が，何が影響したのかは明らかにしていない. ${ }^{44,49)}$ ここでは，SPME 法を用いることでなぜ $\beta$-cyclocitral が分析可能なのかという視点に立ち, $\beta$-cyclocitral が Microcystis 属ラン藻から放出される過 程を明らかにすることを目的として分析法の再検討 を行った。まず， $\beta$-cyclocitral が検出可能な SPME-GC/MS の検証を行った。本法はガラス製バ
イアル中に，液面に接触しないようにファイバーを 挿入し, 水中の揮発物を気相中のファイバーに吸着 させる手法である. 実際の分析では, 目的物をファ イバーに吸着させる，すなわち平衡を達成させるこ とが重要であり, そのために加熱や塩析などの操作 が追加される. $\beta$-Cyclocitral 分析においても同様で あり, 乾燥した $\mathrm{NaCl}$ 添加による塩析, 抽出時の $60^{\circ} \mathrm{C}, 20$ 分の加熱及び超音波を用いた振盪を加え ている。これらの操作は溶媒抽出-GC/MS 法には 含まれないため, $\beta$-cyclocitral 検出に寄与する因子 と予想された。同一のラン藻試料を用いて SPMEGC/MS 法による分析を行い, 分析中の塩析・加 熱・振盪の 3 操作を総当たり方式で除き，それぞれ の $\beta$-cyclocitral 検出量を比較した. 既存の分析法で は $9.7 \mu \mathrm{g} / \mathrm{L} の \beta$-cyclocitral が検出されたのに対 し, 各操作からは異なる結果が得られた。単一操作 のうち加熱操作のみ $\beta$-cyclocitral が検出され，それ 以外では検出されていない。 また, 全 7 種の操作の うち， $\beta$-cyclocitral は 5 種，うち加熱を含む 4 種す べてが該当することから，加熱が $\beta$-cyclocitral の検 出に重要であることが示された. ${ }^{50)}$

溶媒抽出-GC/MS では，ふた付試験管に培養液 と抽出溶媒を加えて振蕰させ, 有機層に目的物を抽 出する. $\beta$-Cyclocitric acid を分析するために抽出前 に $1 \mathrm{M} \mathrm{HCl}$ を加えると, 液性が $\mathrm{pH} 8-10$ から $\mathrm{pH}$ 3 程度になり, $\beta$-cyclocitric acid が分子型へと変化 するため, 溶媒抽出が可能になる. SPME 法にお ける加熱条件は, 分析直前にヘッドスペース内で $60^{\circ} \mathrm{C}, 20$ 分の条件を付与している。 これを再現す るため, 水浴で $60^{\circ} \mathrm{C}, 20$ 分間加熱し, 常温に戻 し, 通常の溶媒抽出-GC/MS 法を用いて分析を 行った。非加熱条件での $\beta$-cyclocitral ピーク面積は 70, 加熱条件ではピーク面積が 796 で, 非加熱サン プルの約 11 倍のピーク面積が得られた。この結果 から, 溶媒抽出法においても加熱条件を付与するこ とにより $\beta$-cyclocitral が定量可能であることが示さ れた。 $\beta$-Cyclocitral の検出には加熱が必要であるこ とが判明したため, 加熱条件の検討を行った. 既知 条件の $60^{\circ} \mathrm{C}, 20$ 分を考慮して, 温度を $20-60^{\circ} \mathrm{C}$, 加熱時間を 0-120 分をそれぞれ検討し，加熱時間は 5 分以上, 温度は $60^{\circ} \mathrm{C}$ が最適であると結論され た. ${ }^{50)}$

上述の一斉分析法において, 酸の添加は SPME- 
GC/MS には含まれず，溶媒抽出-GC/MS でのみ害 行された。この操作は $\beta$-cyclocitric acid を分子型に するためのもので, 通例塩酸を添加後すぐに有機溶 媒を添加し, 3 分程度の振盪の後抽出を行うため, 酸の添加から抽出するまでの時間はおよそ 5 分程度 である. 予備実験で酸性条件が $\beta$-cyclocitral の検出 の可能性を示したことから溶媒抽出法を用いてあら かじめ酸を添加し, 一定時間静置後通常の抽出操作 を行い，分析結果を比較した。0 時間の時点では $\beta$-cyclocitral は定量限界を超えなかったが， 0.5 時 間以上の静置により $\beta$-cyclocitral の検出量が増加し た. 1，3， 6 時間の静置による $\beta$-cyclocitral の検出 量がほぼ同程度であるため, 1 時間以上の酸性条件 で $\beta$-cyclocitral の検出量が頭打ちとなることが示さ れた。また，本条件下 $\beta$-ionone 及び $\beta$-cyclocitric acidの検出量はほとんど増加しなかった。前述し た加熱条件下では $\beta$-cyclocitral は $10 \mu \mathrm{g} / \mathrm{L}$ を超えな かったことに対し，本実験では $60 \mu \mathrm{g} / \mathrm{L}$ と非常に多 量の $\beta$-cyclocitral が検出された。このことから, $\beta$-cyclocitral の検出には加熱のほかに酸添加が有効 であり，1 時間ほどの待ち時間が必要ではあるが, より効果的な条件であることが示された。

\section{6-3. $\beta$-Cyclocitral 生合成のための中間体と新た} なCCD の存在加熱や酸を添加することで $\beta$-cyclocitral が検出可能となることが明らかとな り，これに基づいて過去の分析法を調査すると， $\beta$-cyclocitral の分析法ではいずれも加熱を含む操作

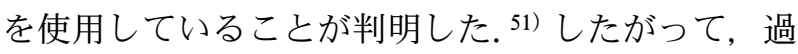
去の分析結果は湖沼における $\beta$-cyclocitral 自身を定 量したものではなく, 加熱後の $\beta$-cyclocitral を検出 しており，本化合物はなんらかの前駆体として存在 していることが示された。既に述べたように，

$\beta$-ionone は $\beta$-carotene を出発物質として CCD に よって産生することが報告されており, ${ }^{52)} \beta$-cyclocitral も同様の経路によって産生されると推察さ れる，CCDによる酵素反応に関しては，Harrison 及び Bugg がその反応機構を提案している. ${ }^{53)}$ 彼ら の酸化開裂反応機構では，2 種の中間体を経ること が報告されており，Fig. 15 中に intermediate-1 及 び 2 として示している.ここで, intermediate-1 か ら $\beta$-cyclocitral が産生される経路にはプロトンが必 要であり, 本実験中の酸添加条件が該当する. また, intermediate-2 は四員環のジオキセタン構造を持

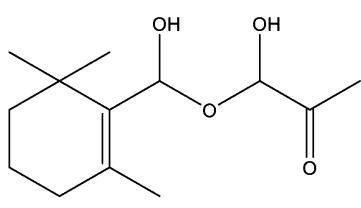

Intermediate-1

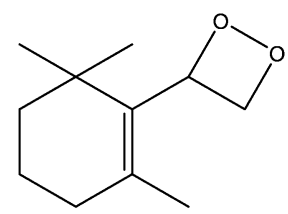

Intermediate-2
Fig. 15. Plausible Intermediates for $\beta$-Cyclocitral Production Based on the CCD Reaction Mechanism by Harrison and Bugg

ち，化学的に立体ひずみが大きく，加熱のようなエ ネルギーが与えられることで， $\beta$-cyclocitral が産生 されることが考えられ，本実験中の加熱条件が該当 する．したがって， $\beta$-cyclocitral が加熱や酸の条件 で検出される背景として，CCD 酵素による反応を 受けて中間体として蓄積されることが予想された. また, 酸添加条件により目的化合物が効率的に検出 されるという結果は，2 種の開裂経路のうち intermediate-1 を経由する反応が優勢であることを示し ており，さらにこの反応を触媒する CCD 酵素が Microcystis 属ラン藻中に存在することが予想され た. $\beta$-Cyclocitral は自身に対しても溶藻活性を有す るため, 細胞中にそのままの形で保持することは考 え難く, 中間体として保持されると考えれば実験結 果とも整合性がとれる.

CCD は植物を中心として様々な研究がなされて おり，多くのサブタイプが存在することが知られて いる. ${ }^{45)}$ ラン藻 $M$. aeruginosa NIES-843 は 2 種の $\mathrm{CCD}, \mathrm{CCD} 7$ 及び ACO を保有している. ゲノム解 読ラン藻として M. aeruginosa NIES-843 の近縁に Synechocystis sp. PCC6803 が存在しているが, 本 株からは $\beta$-cyclocitral は検出されなかった. しかし， $\beta$-cyclocitral の合成には CCD 反応が介在すること が予想され，Microcystis 属ラン藻が $\beta$-cyclocitral を産生するためには，Cui らが報告していない新た な CCD 酵素の存在が示唆された. ${ }^{48)}$ そこで，かず さ DNA 研究所が公開していたラン藻のゲノムデー タベースである “cyanobase”を用いて，Synechocystis sp. PCC6803 を対照として M. aerugino$s a$ NIES-843 の CCD 酵素の探索を行った. ${ }^{54)} M$. aeruginosa NIES-843 には CCD7 である MAE _ 09040 とACO である MAE_60600 の 2 つの CCD が存在する。一方, Synechocystis sp. PCC6803に は CCD7 である AOY38_09620 とACO である 
AOY38_09805の 2 種の CCD がある。これらの 4 種の CCD 酵素について検索を行つたところ，互い に高い相同性が得られた。しかし，M. aeruginosa NIES-843 に対してのみ，MAE_09040 及び MAE 60600 に相同性がある新規酵素，MAE_33390 が発 見された。また，MAE_33390は 4 種の CCD に対 して相同性を示すほか，新たな酵素 MAE_22790 と の相同性も示唆された，結果を整理すると， cyanobase を用いて M. aeruginosa NIES-843 及び Synechocystis sp. PCC6803 が保有する計 4 種の CCD を検索，それぞれに相同性があることを確認した。 さらに, M. aeruginosa NIES-843 に特異的な CCD 酵素候補 MAE_33390 とともに，これにのみ類似性 を持つMAE_22790 も併せて発見したが，本研究期 間中にはこれら 2 種の新規 CCD 酵素の単離及び機 能解析はできなかった。

\section{7. 湖沼生態系における諸現象を化学の目を通し} て考える

本総説では, 神奈川県の相模湖・津久井湖で 1974 年以来 40 年間観察されてきたアオコの形成に 関する現象を扱い，以下の 3 種の特徵的な現象が観 察された：

1）ラン藻類の増殖と減少

2) ラン藻類の青色化を伴う溶藻

3）ラン藻類の種の季節遷移

これらの現象には従来から議論されてきた照度, $\mathrm{pH}$ ，ガス胞，増殖速度，栄養，水温や湖沼の構造 などの因子が関与するとされてきたが，最終的には ラン藻が表層に滞留することに帰結された。本総説 では，滞留したラン藻の中で何が起きているかを追 求した.

\section{1） ラン藻類の増殖と減少}

当然，上述した条件が整えばラン藻類は増殖する が，また適当な条件になれば減少していく，これら はラン藻類の「生活環」として知られ，現象論的に は広く受け入れられている。本研究においては，ラ ン藻類の生活環を制御している因子の 1 つは「細胞 密度」であることが示された。一般に，季節により ラン藻類の増殖程度は異なるが, 晚夏に最も増殖 し，種々の興味深い現象が生起する，特に重要なこ とは，ラン藻類は「細胞密度ストレス」を感じ，よ り自分たちの生存が脅かされないような挙動を取る ことである，単なる観察では理解し難いが，過剩に
なつた細胞は適当な手段でその数を減じるような行 為を行っている．これらに関しては後述する「クオ ラムセンシング (quorum sensing)」の考え方を用 いて説明したい.

2） ラン藻類の青色化を伴う溶藻

青色化を伴う溶藻現象は多くは観察されないこと から，現在までに筆者のグループ以外からの報告は 見当たらない，既に述べたように，筆者はラン藻由 来の VOC を見い出し，これらのうちの 1 つである $\beta$-cyclocitral が極めて酸化され易く， $\beta$-cyclocitric acidに変換され易いことを明らかにした，結果的 に「酸ストレス」が生じ, chlorophyll $a$ や $\beta$-carotene が分解され, phycocyanin が顕在化することに より青色化が生起する。現在までのところ， $\beta$-cyclocitral は Microcystis のみから産生されることか ら，Microcystis が存在しない場合には青色化は観 察されず，白濁することが観察されている．青色化 現象はラン藻の生活環は化学物質により制御されて いる重要な証左の 1 つである。

3） ラン藻類の種の季節遷移

温带に属している相模湖・津久井湖では，初夏あ たりから Aphanizomenon, そして Dolichospermum 種が出現し, 真夏から初秋には Microcystis が 現れ，10 月頃には消失する。このラン藻類の種の 季節遷移には，上述したクオラムセンシングやラン 藻自身が産生するVOCが関与することが判明し た。特に, 出現するラン藻と VOC 間の感受性の違 いが大きく関与している，各 VOC はその溶藻活性 が異なり，それに基づいてラン藻の種により感受性 の差が生じる．結果的に，これは自然界での種の変 遷と一致し，感受性の高い種は, Microcystis が増 殖すると減少する傾向となる。さらに，溶藻現象が 起こらない濃度でも沈降し易くなるなどの影響があ り，種の変遷に $\beta$-cycloctral が関与している可能性 が強く示唆された。

本研究において, 上述の現象に Microcystis が産 生する $\beta$-cycloctral が深く関与していることが明か となった。 $\beta$-Cycloctral はラン藻自身が有する CCD により産生されると考えられているが，いま だそれを明らかにした報告は存在しない，M. aeruginosa NIES-843 に存在する 2 種の既知 CCD では $\beta$-cycloctral は産生されず，Synechocystis sp. PCC6803 の CCD 酵素の一致率を比較したところ, 


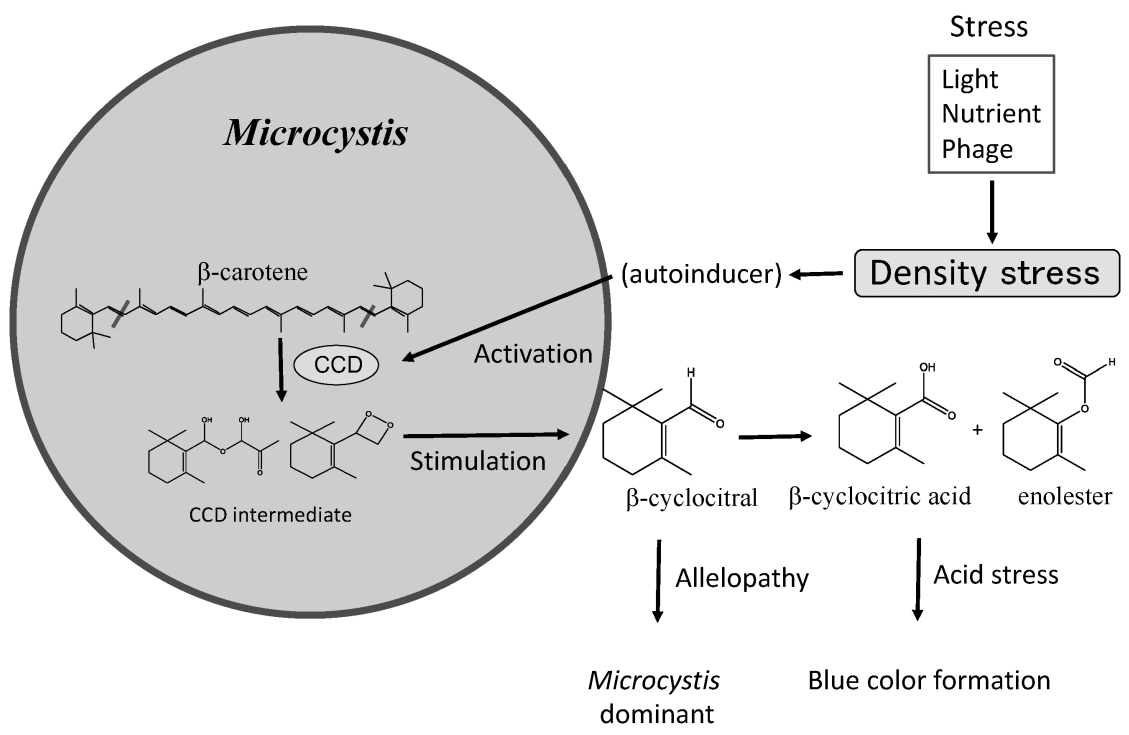

Fig. 16. Summary of the Present Study for Clarification of the Three Interesting Issues Based on 40 Years of Observations

M. aeruginosa NIES-843 に特異的な配列が 2 種発 見され，これらが $\beta$-cyclocitral を産生するCCD で ある可能性が浮上した。 また，これらのCCDによ り直接的に $\beta$-cycloctral を産生するのではなく，そ の前駆体で細胞内に蓄積され，適当な条件下，実験 室的には加熱や酸性条件, 野外ではでは共存微生物 などで目的化合物に変換されると推察された。放出 された $\beta$-cyclocitral は Baeyer-Villiger 様の酸化が進 行し, $\beta$-cyclocitric acid と 2,6,6-trimethylcyclohex1-en-1-yl formate 経由で 2,2,6-trimethylcyclohexanone を与える.

Microcystis 属ラン藻は湖沼生態系において, 高 密度かつ定常期に到達すると新規に推定された $\mathrm{CCD}$ 遺伝子の発現が充進され, $\beta$-cyclocitral の中 間体まで反応が進む．引き続いて，なんらかの刺激 で $\beta$-cyclocitral が産生されると周りのラン藻を溶解 させることになる。この機能を適切に制御するため に $\beta$-cyclocitral は, 極めて特異的な機能を備えてい る。まず，産生された $\beta$-cyclocitral は揮発性であ り，水中に長く滞留せず，その一部は空気中に霧散 する．事実，青色化を伴う溶藻現象が局所的に発生 しており, ${ }^{37)}$ 湖沼のラン藻を死滅させ過ぎない制御 機構とも考えられる。また，上述したように， $\beta$-cyclocitral は Baeyer-Villiger 様の酸化が進行し, $\beta$-cyclocitric acid と 2,2,6-trimethylcyclohexanone を 与えるが，これらの生成物は $\beta$-cyclocitral よりその 溶藻活性は減じられており，ここでもラン藻へのダ
メージを抑える仕組みが工夫されている。 また, $\beta$-cyclocitric acid が水中に蓄積し湖沼が酸性化され ることで，連鎖的にMicrocystis 属ラン藻から $\beta$-cyclocitral が放出され，条件が揃えば青色化を伴う溶 藻現象として観察される.

Microcystis は, なんらかの刺激で CCD 遺伝子が 活性化され， $\beta$-cyclocitral が生成され，他の藻類に 対してアレロパシー物質として働くと推察される.

Microcystis のアレロパシーについては，緑藻55,56) や珪藻57)への作用の報告がある。最近, Chia らは Microcystis と Anabaena 属ラン藻 (Dolichospermum 3 株, Anabaena 1 株）の混合又は細胞を除去 したろ液を用いての培養実験から, Microcystis 培 養液からの無細胞ろ液は Anabaena の増殖を著しく 阻害したと報告している. ${ }^{58)}$ おそらく，この現象に も $\beta$-cyclocitral が関与していると考えている.

Microcystis 属はラン藻類の中でも強い浮上能を持 ち, より効率的に光合成を受けるために行動するこ とが知られている. ${ }^{59)}$ 湖沼において，栄養素や日光 の確保は彼らにとって非常に重要であり， $\beta$-cyclocitral による溶藻は同種を含めた細胞数の調節・ 自身の優占化・栄養塩の回収など様々な利点を有 し, 生存戦略上重要な化合物であることが推察され る.

高密度になったラン藻では, 少なくともその細胞 の周辺は栄養濃度が低下するためなんらかの形で細 胞数と栄養のバランスを調節しなければならない. 
Microcystis 属ラン藻は一体どのようにしてその細 胞数を調節しているのだろうか. 本研究で明らかに なった Microcystis 属ラン藻に関する知見を Fig. 16

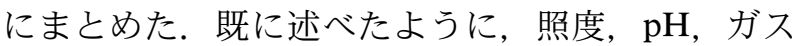
胞, 増殖速度, 栄養, 水温や湖沼の構造などの因子 はすべてラン藻が表層に滞留することに帰結され た。ここではこの刺激が「密度ストレス」という形 で周辺に存在するラン藻に伝わり, “オートイン デューサー (autoinducer)”なるものが放出され, 細胞密度を感知する。今回の実験では本化合物は特 定できていないが，Microcystis はこの機構により $\mathrm{CCD}$ 遺伝子が活性化され， $\beta$-cyclocitral が生成さ れ，他の藻類に対してアレロパシー物質として働く と推察される。結果的に, Microcystis を始めとす るラン藻類の細胞数は減少し, 結果的に生じた窒素 やリンが生存しているラン藻の栄養となることにな る．おそらく，上述した「ラン藻類の増殖と減少」 にこの「クオラムセンシング」が機能していると考 察している. ${ }^{60)}$

本研究は, 溶藻性化合物の探索においてラン藻由 来の溶藻活性化合物を偶然発見したことに端を発す る.なぜラン藻自身が一見すると自殺を行うかのよ うな化合物を産生するのか。 その疑問からラン藻の 生活環の解明に挑夕, 課題や議論の余地が残されて いるものの，晚夏の細胞数調節とみられる生活環の 一部を解明した。従来の各種生物的及び無生物的な 条件とは異なり，適切な有機化合物を座標軸として 湖沼生態系で起こる現象との関連を追跡する，いわ ゆる化学生態学的アプローチにより更なる知見を得 られることが期待され，この試みが湖沼生態学を推 し進める一助となると考えている.

謝辞本退職記念総説の執筆にあたり長年にわ たり共同研究をして頂ました下記の皆様に深謝いた します。过 清美博士，尾崎恵子博士，藤瀬大輝博 士，長谷川真照博士，Beata Bober 博士，有井鈴江 博士，山下竜司博士，冨田浩嗣修士，太田朱美修士.

利益相反＼cjkstart開示すべき利益相反はない.

\section{REFERENCES}

1) Watanabe Y., "Waterbloom of blue - green algae and their toxin," ed. by Watanabe F.
M., Harada K.-I., Fujiki H., University of Tokyo Press, Tokyo, 1994, pp. 1-24.

2) Watanabe F. M, “Toxic Microcystis," ed. by Watanabe F. M., Harada K.-I., Carmichael W. W., Fujiki H., CRC Press, Boca Raton, 1966, pp. 13-34.

3) Arii S., Tsuji K. Harada K.-I., Jpn. J. Limnol., 81, 1-17 (2020).

4) Uchida H., Kouchiwa T., Watanabe K., Kawasaki A., Hodoki Y., Otani I., Yamamoto Y., Suzuki M., Harada K.-I., Jpn. J. Water Tret. Biol., 34, 67-75 (1998).

5) Harada K.-I., Tsuji K., Ohta A., Takayanagi K., Tamaki S., Suzuki T., Ozaki K., Ito E., Fujii K., J. Res. Inst. Meijo Univ., 6, 17-28 (2007).

6) Wright S. J. L., Thompson R. J., FEMS Microbiol. Lett., 30, 263-267 (1985).

7) Wright S. J. L., Linton C. J., Edwards R. A., Drury E., Lett. Appl. Microbiol., 13, 130-132 (1991).

8) Kato H., Imanishi S. Y., Tsuji K., Harada K.-I., Water Res., 41, 1754-1762 (2007).

9) Ozaki K., Ohta A., Iwata C., Horikawa A., Tsuji K., Ito E., Ikai Y., Harada K.-I., Chemosphere, 71, 1531-1539 (2008).

10) Jüttner F., Appl. Environ. Microbiol., 47, 814-820 (1984).

11) Jüttner F., Höflacher B., Arch. Microbiol., 141, 337-343 (1985).

12) Jüttner F., Wat. Sci. Technol., 31, 69-78 (1995)

13) Ikawa M., Sasner J. J., Haney J. F., Hydrobiologia, 443, 19-22 (2001).

14) Vilanova X., Casanovas M., J. Invest. Dermatol., 20, 447 (1953).

15) Knobloch K., Pauli A., Iberl B., Weigand H., Weis N., J. Essent. Oil Res., 1, 119-128 (1989).

16) Griffin S. G., Wyllie S. G., Markham J. L., Leach D. N., Flavour Fragr. J., 14, 322-332 (1999)

17) Vrakas D., Giaginis C., Tsantili-Kakoulidou A., J. Chromatogr. A, 1116, 158-164 (2006) .

18) Rocher F., Chollet J.-F., Jousse C., Bonnemain J.-L., Plant Physiol., 141, 1684-1693 (2006)

19) Zakarya D., Fkih-Tetouani S., Hajii F., Plantes Med. Phytother. 26, 319-331 (1993). 
20) Abe F., Horikoshi K., Cell Mol. Biol. Lett., 10, 1565-1568 (2005).

21) Dickinson J. R., Lanterman M. M., Danner D. J., Pearson B. M., Sanz P., Harrison S. J., Hewlins M. J., J. Biol. Chem., 272, 2687126878 (1997).

22) Schoondermark-Stolk S. A., Jansen M., Veurink J. H., Verkleij A. J., Verrips C. T., Euverink G. J., Boonstra J., Dijkhuizen L., Appl. Microbiol. Biotechnol., 40, 237-246 (2006).

23) Hasegawa M., Nishizawa A., Tsuji K., Kimura S., Harada K.-I., Microbes Environ., 27, 525-528 (2012).

24) Kern K., Nunn C. D., Pichová A., Dickison J. R., FEMS Yeast Res., 5, 43-49 (2004).

25) Ozaki K., Ito E., Tanabe S., Natsume K., Tsuji K., Harada K.-I., J. Health Sci., 55, 578585 (2009).

26) Yoshikawa K., Adachi K., Nishijima M., Takadera T., Tamaki S., Harada K.-I., Mochida K., Sano H., Appl. Environ. Microbiol., 66, 718-722 (2000).

27) Yamamoto Y., Kouchiwa T., Hodoki Y., Hotta K., Uchida H., Harada K.-I., J. Appl. Phycol., 10, 391-397 (1998).

28) Harada K.-I., Ozaki K., Tsuzuki S., Kato H., Hasegawa M., Kuroda E. K., Arii S., Tsuji K., J. Chem. Ecol., 35, 1295-1301 (2009) .

29) Huang J. J., Kolodny N. H., Redfearn J. T., Allen M. M., Arch. Microbiol., 177, 486-493 (2002).

30) Tomita K., Hasegawa M., Arii S., Tsuji K., Bober B., Harada K.-I., Environ. Sci. Pollut. Res., 23, 11998-12006 (2016).

31) Shilo M., Bacteriol. Rev., 31, 180-193 (1967).

32) Fallon R. D., Brock T. D., Appl. Environ. Microbiol., 38, 499-505 (1979).

33) Nishibe Y., Kawabata Z., Nakano S., Aquat. Microbiol. Ecol., 29, 173-179 (2002).

34) Pearl H. W., Fulton R. S., Moisander P. H., Dyble J., The Scientific World Journal, 1, 76113 (2001).

35) Pearl H. W. Hall N. S., Calandrino E. S., Sci. Total Environ., 409, 1739-1745 (2011).

36) Pearl H. W., Life, 4, 988-1012 (2014).

37) Arii S., Tsuji K., Tomita K., Hasegawa M., Bober B., Harada K.-I., Appl. Environ. Microbiol., 81, 2667-2675 (2015).
38) Arii S., Tomita K., Tsuji K., Harada K.-I., J. Res. Inst. Meijo Univ., 15, 11-16 (2016).

39) Arii S., Yamashita R., Tsuji K., Tomita K., Hasegawa M., Bober B., Harada K.-I., Chemosphere, 284, 131378 (2021).

40) Nakamura K., Homma T., Miyabara Y., Hanazato T., Park H.-D., J. Jpn. Soc. Water Environ., 33, 123-129 (2010).

41) Arii S., Tsuji K., Tomita K., Hasegawa M., Yamashita R., Bober B., Harada K.-I., Phycol. Res., 66, 161-166 (2018).

42) Crayton M. A., "Toxic cyanobacterial blooms: a field/laboratory guide,"' 1993.

43) Auldridge M. E., McCarty D. R., Klee H. J., Curr. Opin. Plant Biol., 9, 315-321 (2006).

44) Fujise D., Tsuji K., Fukushima N., Kawai K., Harada K.-I., J. Chromatogr. A, 1217, 61226125 (2010).

45) Havaux M., Plant Physiol. Biochem., 155, 3541 (2020).

46) Kaneko T., Nakajima N., Okamoto S., Suzuki I., Tanabe Y., Tamaoki M., Nakamura Y., Kasai F., Watanabe A., Kawashima K., Kishida Y., Ono A., Shimizu Y., Takahashi C., Minami C., Fujishiro T., Kohara M., Katoh M., Nakazaki N., Nakayama S., Yamada M., Tabata S., Watanabe M. M., DNA Res., 14, 247-256 (2007).

47) Kaneko T., Tabata S., Plant Cell Physiol., 38, 1171-1176 (1997).

48) Cui H., Wang Y., Qin S., Com. Funct. Genomics, 164690 (2012).

49) Zhang K., Lin T. F., Zhang T., Li C., Gao N., J. Environ. Sci. (China), 25, 1539-1548 (2013).

50) Yamashita R., Bober B., Kanei K., Arii S., Tsuji K., Harada K.-I., Molecules, 25, 832 (2020).

51) Watson S. B., Monis P., Baker P., Giglio S., Harmful Algae, 54, 112-127 (2016).

52) Sommerburg O., Langhans C. D., Arnhold J., Leichsenring M., Salerno C., Crifò C., Hoffmann G. F., Debatin K. M., Siems W. G., Free Radic. Biol. Med., 35, 1480-1490 (2003).

53) Harrison P. J., Bugg T. D. H., Arch. Biochem. Biophys., 544, 105-111 (2014).

54) "CyanoBase": 〈http://genome.kazusa.or.jp/ cyanobase $\rangle$, cited 27 November, 2021.

55) Leão P. N., Vasconcelos M. T. S. D., Vascon- 
celos V. M., Eur. J. Phycol., 44, 347-355 (2009).

56) Dunker S., Jakob T., Wilhe C., Freshw. Biol., 58, 1573-1587 (2013).

57) Wang L., Zi J., Xu R., Hilt S., Hou X., Chang X., Harmful Algae, 61, 56-62 (2017).

58) Chia M. A., Jankowiak J. G., Kramer B. J.,
Gloleski J. A., Huang I.-S., Zimba P. V., Bittencourt-Oliveira M. C., Gobler C. J., Harmful Algae, 74, 67-77 (2018).

59) Ganf G. G., Oliver R. L., J. Ecol., 70, 829844 (1982).

60) Ikeda T., Seibutsu-kogaku Kaishi, 90, 582-585 (2012). 